\title{
Size distribution of particles and zooplankton across the shelf-basin system in southeast Beaufort Sea: combined results from an Underwater Vision Profiler and vertical net tows
}

\author{
A. Forest ${ }^{1}$, L. Stemmann ${ }^{2}$, M. Picheral ${ }^{2}$, L. Burdorf ${ }^{2}$, D. Robert ${ }^{1}$, L. Fortier ${ }^{1}$, and M. Babin ${ }^{1}$ \\ ${ }^{1}$ Takuvik Joint International Laboratory, UMI 3376, Université Laval (Canada) - CNRS (France), \\ Département de Biologie and Québec-Océan, Université Laval, G1V 0A6, Canada \\ ${ }^{2}$ Laboratoire d'Océanographie de Villefranche, Université Pierre et Marie Curie-Paris 6 and CNRS, \\ 06230 Villefranche-sur-Mer, France
}

Correspondence to: A. Forest (alexandre.forest@ takuvik.ulaval.ca)

Received: 3 November 2011 - Published in Biogeosciences Discuss.: 28 November 2011

Revised: 11 March 2012 - Accepted: 18 March 2012 - Published: 10 April 2012

\begin{abstract}
The size distribution and mean spatial trends of large particles $(>100 \mu \mathrm{m}$, in equivalent spherical diameter, ESD) and mesozooplankton were investigated across the Mackenzie Shelf (southeast Beaufort Sea, Arctic Ocean) in July-August 2009. Our main objective was to combine results from an Underwater Vision Profiler 5 (UVP5) and traditional net tows $(200 \mu \mathrm{m}$ mesh size) to characterize the structural diversity and functioning of the Arctic shelf-basin ecosystem and to assess the large-scale correspondence between the two methodological approaches. The core dataset comprised 154 UVP5 profiles and 29 net tows conducted in the shelf $(<100 \mathrm{~m}$ isobath), slope $(100-1000 \mathrm{~m})$ and basin $(>1000 \mathrm{~m})$ regions of the study area. The mean abundance of total particles and zooplankton in the upper water column ( $<75 \mathrm{~m}$ depth) declined exponentially with increasing distance from shore. Vertical and latitudinal patterns in total particle concentration followed those of chlorophyll $a(\operatorname{chl} a)$ concentration, with maximum values between 30 and $70 \mathrm{~m}$ depth. Based on the size-spectra derived from the UVP5 dataset, living organisms $(0.1-10 \mathrm{~mm}$ ESD) accounted for an increasingly large proportion of total particle abundance (from $0.1 \%$ to $>50 \%$ ) when progressing offshore and as the ESD of particles was increasing. Both the UVP5 and net tows determined that copepods dominated the zooplankton community ( $\sim 78-94 \%$ by numbers) and that appendicularians were generally the second most abundant group $(\sim 1-11 \%)$. The vertical distribution patterns of copepods and appendicularians indicated a close association between
\end{abstract}

primary production and the main grazers. Manual taxonomic counts and ZooScan image analyses shed further light on the size-structure and composition of the copepod community - which was dominated at $\sim 95 \%$ by a guild of 10 typical taxa. The size distributions of copepods, as evaluated with the 3 methods (manual counts, ZooScan and UVP5), showed consistent patterns co-varying in the same order of magnitude over the upper size range ( $>1 \mathrm{~mm}$ ESD). Copepods $<1 \mathrm{~mm}$ were not well quantified by the UVP5, which estimated that only $\sim 13-25 \%$ of the assemblage was composed of copepods $<1 \mathrm{~mm}$ ESD compared with $\sim 77-89 \%$ from the net tow estimates. However, the biovolume of copepods was overwhelmingly dominated $(\sim 93-97 \%)$ by copepods $>1 \mathrm{~mm}$ ESD. Our results illustrate that the combination of traditional sampling methods and automated imaging techniques is a powerful approach that enabled us to conclude on the prevalence of a relatively high productivity regime and dominant herbivorous food web over the shelf when compared with the low-productive recycling system detected offshore. 


\section{Introduction}

Particles in aquatic systems can be divided in two fundamental groups: living and non-living.

Size of non-living particles (named marine snow for sizes $>500 \mu \mathrm{m}$; Suzuki and Kato, 1953) is the net result of aggregation and destruction processes, which include a large variety of physical and biological mechanisms such as coagulation, packaging, consumption, dissolution and fragmentation (see Burd and Jackson, 2009 for a review). The particle size distribution (PSD) of non-living particles is particularly instructive for vertical flux studies if the settling velocity of observed particles is known (e.g. McDonnell and Buesseler, 2010) or if the PSD can be related to sediment trap measurements (e.g. Guidi et al., 2008; Iversen et al., 2010). In turn, numerical models of biogeochemical fluxes used simplified PSD to estimate the magnitude and timing of sinking particle flux events (e.g. Kriest and Evans, 2000; Stemmann et al., 2004; Karakas et al., 2009). However, the strength and efficiency of the biological pump are closely connected to the aforementioned transformation processes in the water column, which are indeed largely driven by planktonic communities, including bacteria, protists and metazoans (e.g. Wassmann et al., 2003; Forest et al., 2011; Jackson and Checkley, 2011; Kellogg et al., 2011). Therefore, knowledge on the contribution of living particles to the total particle pool and on the plankton size distribution is essential if the dynamics of downward carbon export and trophic energy fluxes are to be adequately understood and modeled in marine ecosystems. Information on the variability of the size spectrum of particles support the characterization of various ecological processes and is key to our comprehension of the structure and function of pelagic food webs (e.g. Platt and Denman, 1978; Legendre and Michaud, 1998; Stemmann and Boss, 2012).

The PSD of living particles (i.e. plankton) is recognized to be useful for describing the structural properties of a given marine food web. When converted into biomass, variations in the slope of the normalized PSD on a logarithmic scale can be linked to efficiencies in both the energy transfer to higher trophic levels and vertical carbon export to depth (e.g. Guidi et al. 2009; Frangoulis et al., 2010). Anomalies in the shape of the log-transformed plankton size distribution may also be indicative of excess growth/mortality or gain/losses through consumption or migration (Zhou et al., 2006; Frangoulis et al., 2010). Furthermore, size-based analysis of living particles provides a valuable tool in ecosystem modeling for reducing the complexity of actual food webs and species interactions (Zhou et al., 2010). For example, sizestructured ecosystem models can unravel shifts in the diet of zooplankton when the latter grow, since large organisms usually consume smaller ones (Platt and Denman, 1978). Species-oriented or functional group modeling approaches of trophic networks cannot solve this issue (Moloney et al., 2010). This is particularly true for Arctic regions where marine ecosystems experience marked seasonal variability in biological productivity as a direct consequence of physical conditions (e.g. light, temperature). As a result, Arctic zooplankton can rapidly change their food regime depending on the nature and availability of organic matter in their environment. In fact, even the large calanoid species Calanus hyperboreus and C. glacialis that typically dominate the biomass in the Arctic Ocean - and which are traditionally known to be herbivore (Darnis et al., 2008; FalkPetersen et al., 2009) - appear to have a much more flexible diet (e.g. fecal detritus, microzooplankton) than initially believed (e.g. Seuthe et al., 2007; Campbell et al., 2009; Sampei et al. 2009).

This study investigated the PSD of large particles $>100 \mu \mathrm{m}$ (total and zooplankton, expressed in equivalent spherical diameter, ESD) across the shelf-slope-basin interface in the southeast Beaufort Sea (Arctic Ocean) in late July-August 2009 (Fig. 1). Our main goal was to combine results from an Underwater Vision Profiler 5 (UVP5, Picheral et al., 2010) and from traditional net tows to infer the structure and functioning of an Arctic shelf ecosystem during the late summer season. Our specific objectives were (1) to document with high-vertical resolution imaging techniques the large-scale trends of PSD and particle concentration across the shelf-basin boundary; (2) to examine the degree of similarity between the zooplankton dataset acquired with the UVP5 and the one obtained using standard vertical net tows; (3) to characterize the size spectra of total particles and zooplankton in an ecosystem known for its relatively low diversity; and (4) to set the stage for a comprehensive study on vertical particle fluxes and ecosystem dynamics in the southeast Beaufort Sea during post-bloom conditions.

\section{Material and methods}

\subsection{Study area and sampling strategy}

The Mackenzie Shelf (Fig. 1) is a relatively narrow Arctic shelf (width $\sim 120 \mathrm{~km}$, length $\sim 530 \mathrm{~km}$ ) covered with ice from October until May to early August, reaching a maximum thickness of 2-3 $\mathrm{m}$ in March-April (Barber and Hanesiak, 2004). The Mackenzie River supplies $\sim 330 \mathrm{~km}^{3} \mathrm{yr}^{-1}$ of freshwater and $124 \times 10^{6} \mathrm{tyr}^{-1}$ of sediment on the shelf (Gordeev, 2006). Approximately $75 \%$ of the total annual discharge is delivered between May and September, with a typical peak in June. As the summer progresses, both river runoff and ice melt contribute to build up a strongly stratified surface layer in the top 5-10 m (Carmack and Macdonald, 2002). Saltwater masses in the region comprise the Polar-Mixed Layer (salinity $<31, \sim 0-50 \mathrm{~m}$ depth), the Pacific Halocline $(\sim 31-33, \sim 50-200 \mathrm{~m})$, and deep waters of Atlantic origin $(\sim 34.5,>220 \mathrm{~m})$ (Lansard et al., 2012). Surface circulation is variable and linked to ice and wind conditions (Ingram et al., 2008). Inshore, a typical coastal current 


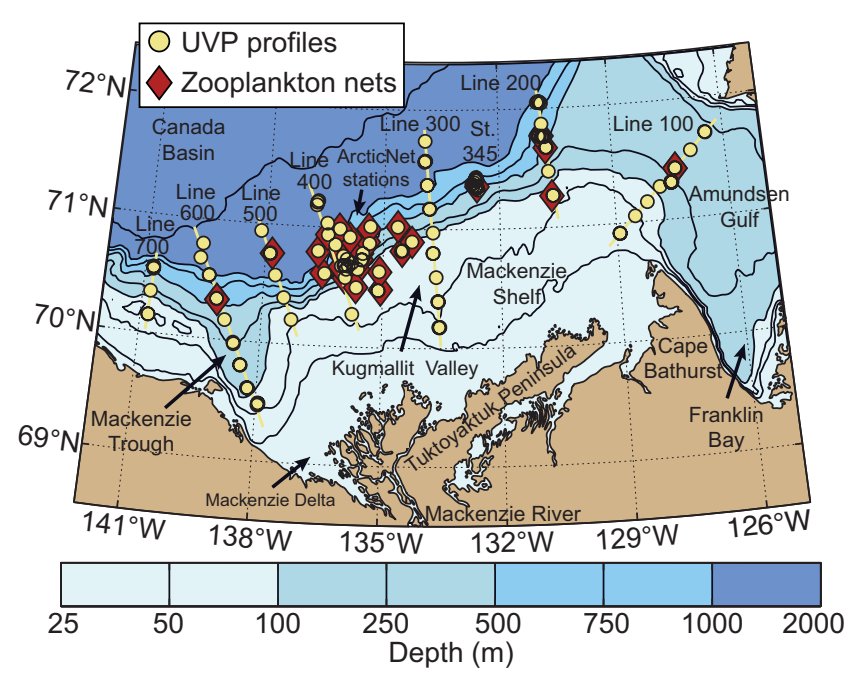

Fig. 1. Bathymetric map of the southeast Beaufort Sea (Arctic Ocean) with position of the sampling stations conducted in JulyAugust 2009 as part of the successive ArcticNet and Malina campaigns. The ArcticNet sampling sites were located in the exploration license area EL446, whereas transects 100-700 and station 345 correspond to the Malina sampling grid. The shelf, slope and basin regions as defined in the present study correspond to the sampling stations located within the $<100 \mathrm{~m}, 100-1000 \mathrm{~m}$ and $>1000 \mathrm{~m}$ isobaths, respectively. The metadata (coordinates, date, sampling type) for each oceanographic station are detailed in the Appendix A.

flows from west to east, whereas offshore surface circulation is overall influenced by the anti-cyclonic Beaufort Gyre (Ingram et al., 2008).

Primary production in the Beaufort Sea usually ranges from 30 to $70 \mathrm{~g} \mathrm{C} \mathrm{m}^{-2} \mathrm{yr}^{-1}$, indicative of oligotrophic conditions (Sakshaug, 2004; Carmack et al., 2004). The spring bloom rapidly evolves into a subsurface chlorophyll maximum (SCM) as a result of relatively low nitrate concentrations in the surface layer at the end of winter (Tremblay et al., 2008). Over the growth season, the SCM progressively lowers the nitracline down to $\sim 60 \mathrm{~m}$ depth where light becomes the limiting factor (Martin et al., 2010). A second phytoplankton bloom can occur in late summer or in the fall as a result of wind-driven mixing and/or coastal upwelling (Brugel et al., 2009).

Data used in the present study were collected across the Mackenzie Shelf region between 18 July and 22 August 2009 during the successive ArcticNet and Malina campaigns that took place on board the research icebreaker CCGS Amundsen (Fig. 1, Appendix A). The first leg (16-29 July) was a component of the annual expedition of the ArcticNet Network aiming to assess ecosystem dynamics in coastal waters of the Canadian Arctic. The second leg (30 July27 August) was led by the Malina project, which covered the Mackenzie Shelf region with a comprehensive sampling grid primarily composed of 7 shelf-basin transects
(Fig. 1). The data collected over ArcticNet-Malina was divided according to bottom depth in order to investigate the mean inshore-offshore gradients in total particle concentration, zooplankton abundance, as well as associated volume/biomass and size distribution. The shelf, slope and basin regions were defined as the sampling stations located within the $<100 \mathrm{~m}, 100-1000 \mathrm{~m}$ and $>1000 \mathrm{~m}$ isobaths, respectively. This grouping enabled us to evaluate the largescale variations and to process the CTD, UVP5 and net tow datasets on the basis of an independent variable.

\subsection{Underwater Vision Profiler, CTD-rosette casts and image processing}

The Underwater Vision Profiler 5 (UVP5) is a compact and autonomous underwater imaging system developed and initially constructed at the Laboratoire d'Océanographie de Villefranche-sur-Mer (LOV) located in southern France. The instrument is now manufactured by HydroptiC (http://www. hydroptic.com/) in collaboration with the LOV. Full details of the technical specifications and processing operations of the UVP5 can be found in Picheral et al. (2010).

The UVP5 used in the present study was designed to be a component of the rosette profiler equipped with a conductivity-temperature-depth system (CTD, Seabird SBE911+) and was deployed on a routine basis throughout the campaign (Fig. 1). Most CTD/UVP-rosette vertical profiles were conducted over the whole water column, i.e. from the surface down to $10 \mathrm{~m}$ above the sea floor (see Appendix A for the list of stations). A fluorometer (Seapoint chlorophyll fluorometer) and a transmissometer (WET Labs C-Star $25 \mathrm{~cm}$ ) were also connected to the CTD system. The CTD data were calibrated and verified following the Unesco Technical Papers (Crease, 1988). Water samples were taken on board for salinity calibration using a Guildline Autosal salinometer (resolution $<0.0002$, precision \pm 0.002 ). Fluorescence data from the fluorometer were post-calibrated against in situ chlorophyll $a(\mathrm{chl} a)$ concentrations. Validated data from all CTD casts were averaged over $5 \mathrm{~m}$ bins using a centered moving average.

During deployment, the UVP5 recorded and measured all objects $>100 \mu \mathrm{m}$ in real time (i.e. both non-living particles and zooplankton). Images of all particles were recorded at a frequency up to $5.5 \mathrm{~Hz}$, corresponding to a distance of $\sim 20 \mathrm{~cm}$ between images at the $\sim 1 \mathrm{~m} \mathrm{~s}^{-1}$ lowering speed of the CTD-rosette profiler. The recorded volume per image was 1.021 and the conversion equation from pixel area to size was $S_{\mathrm{m}}=0.003 S_{\mathrm{p}}^{1.3348}$, where $S_{\mathrm{m}}$ is the surface in $\mathrm{mm}^{2}$ and $S_{\mathrm{p}}$ the particle area in number of pixels (Picheral et al., 2010). The real time processing was set to a mixed process mode. The size and grey level of every object $>100 \mu \mathrm{m}$ were calculated in situ, but only images of all large objects $>600 \mu \mathrm{m}$ were backed up on a memory stick for further analysis. When the UVP5 was back on the ship deck, both the complete dataset of total particles and the logged images of 
objects $>600 \mu \mathrm{m}$ were transferred on a computer for complete analysis. The size spectra of total particle abundance and volume were computed at an interval of $5 \mathrm{~m}$. Images of all objects $>600 \mu \mathrm{m}$ were processed using the Zooprocess imaging software (http://www.zooscan.com) in order to calculate 40 geometric and grey-level variables to identify major zooplankton by the freeware Plankton Identifier (PkID) based on Tanagra data mining and implemented as part of the Zooprocess package (see Gorsky et al., 2010 for details). The prediction of organisms obtained from the PkID files was exhaustively post-validated by experts to obtain an accurate dataset of abundance and biovolume for zooplankton larger than $600 \mu \mathrm{m}$.

The size distributions of the abundance and volume of total particles and zooplankton recorded at each station were normalized according to the interval of each size-class (Platt and Denman, 1978). This dataset was then divided and averaged for the shelf $(<100 \mathrm{~m}$ isobath), slope $(100-1000 \mathrm{~m})$ and basin ( $>1000$ ) regions to provide a more comprehensive overview of particle dynamics and large-scale spatial trends across the inshore-offshore interface (Fig. 1, Appendix A). The relationship between the abundance/volume and the size of particles/zooplankton was approximated by the two-parameter power-law equation $n=b d^{k}$, where $n$ is the normalized particle abundance or volume, $b$ a constant, $k$ the scaling exponent (slope in a log-log form) and $d$ the equivalent spherical diameter (ESD) of a given particle or organism (also referred as apparent diameter, see Stemmann and Boss, 2012 for further details).

\subsection{Zooplankton net tows, traditional taxonomic counts and ZooScan measurements}

Zooplankton assemblage integrated over the entire water column was collected using a quadruple $1 \mathrm{~m}^{2}$ metal frame sampler equipped with flowmeters and plankton nets of $200 \mu \mathrm{m}$ mesh size (Darnis et al., 2008). At each station (see Appendix A), the sampling gear was deployed vertically from $10 \mathrm{~m}$ above the bottom up to the surface at a speed of $45 \mathrm{~m} \mathrm{~min}^{-1}$. Zooplankton samples were condensed and preserved in seawater solution poisoned with boraxbuffered $4 \%$ formalin for further analysis. Preserved samples were divided in two distinct fractions in order to proceed to: (1) manual taxonomic counts; and (2) sample digitization and analysis using a ZooScan (Gorsky et al., 2010). ZooScan digitization and image post-processing with the Zooprocess software were made at LOV (Villefranche-surMer, France), whereas traditional taxonomy and validation of random ZooScan vignettes were performed at Laval University (Québec, Canada).

Subsamples for manual taxonomy were rinsed with freshwater and sieved through 1000 and $150 \mu \mathrm{m}$ meshes to separate large and small organisms. The two size fractions $(<1000 \mu \mathrm{m}$ and $>1000 \mu \mathrm{m})$ were divided with a Motodatype splitting box and known aliquots were resuspended
Table 1. Performance of the automatic recognition for the zooplankton groups analyzed using the ZooScan.

\begin{tabular}{lll}
\hline & $\begin{array}{l}\text { True positive } \\
\text { (recall rate) }\end{array}$ & $\begin{array}{l}\text { False positive } \\
\text { (contamination rate) }\end{array}$ \\
\hline Appendicularians & $66.7 \%$ & $32.9 \%$ \\
Copepods* & $84.9 \%$ & $19.4 \%$ \\
Detritus & $78.1 \%$ & $20,5 \%$ \\
Carnivorous gelatinous & $63.0 \%$ & $34.3 \%$ \\
\hline
\end{tabular}

*Do not include nauplii

in distilled water. From each sub-sample, approximately 300 zooplankton organisms were enumerated in a Bogorov counting tray and identified to the lowest possible taxonomical level. The Arctic copepod species Calanus glacialis and the Pacific Subarctic C. marshallae that may co-occur in the region (Frost, 1974) were pooled into a single taxon due to lack of certainty in their differentiation (Darnis et al., 2008).

Subsamples for ZooScan analyses were also divided with a Motoda splitter, resuspended in distilled water and fractionated to obtain two size-fractions $(<1000 \mu \mathrm{m}$ and $>1000 \mu \mathrm{m})$. Each size-fractionated sample was gently poured in a $15 \times 24 \mathrm{~cm}$ Plexiglas tray on the scanner ( $2400 \mathrm{dpi}$ resolution). Prior to digitization, manual separation of plankton organisms with fine tweezers was performed directly into the tray to avoid multiple objects to be treated as one. In some cases, separation of objects was also performed computationally after digitization. Scanned samples were normalized using the full spectrum of grey and a blank (i.e. scan without objects) was subtracted from each image. The Zooprocess software was used to extract and measure every object detected in images produced by the ZooScan (pixel resolution of $10.6 \mu \mathrm{m}$ ). The major and minor axis of the best fitting ellipse for each object were measured and an equivalent apparent elliptical biovolume (EBv) was estimated as: $\mathrm{EBv}=4 / 3 \cdot \pi \cdot($ major $/ 2) \cdot(\operatorname{minor} / 2)^{2}$. Many other variables $(\mathrm{Ap}-$ pendix 4 in Gorsky et al., 2010) were also used for the automatic classification of objects. The automatic recognition of zooplankton was performed using the free software PkID as mentioned in Sect. 2.2. The training set for ZooScan consisted of 2100 validated vignettes of random objects (including detritus). The training set algorithm was used to classify organisms from the net tow samples in major zooplankton groups. Comparison between machine-predicted recognition and manually validated classifications showed that copepods were successfully recognized (true positive $=84.9 \%$, contamination $=19.4 \%$ ) while appendicularians were less recognized (true positive $=66.7 \%$, contamination $=32.9 \%$ ) (Table 1). The automatic prediction was then corrected by a manual validation to ensure accurate estimate of zooplankton groups. 


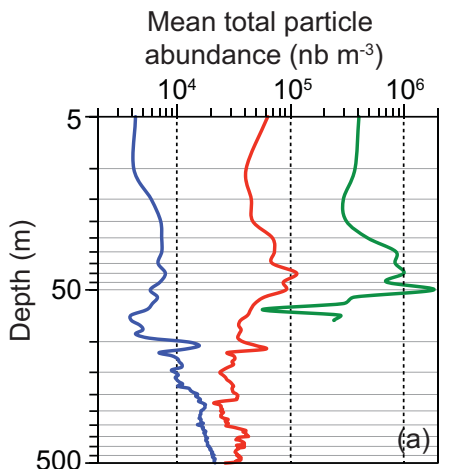

Mean zooplankton abundance (ind $\mathrm{m}^{-3}$ )
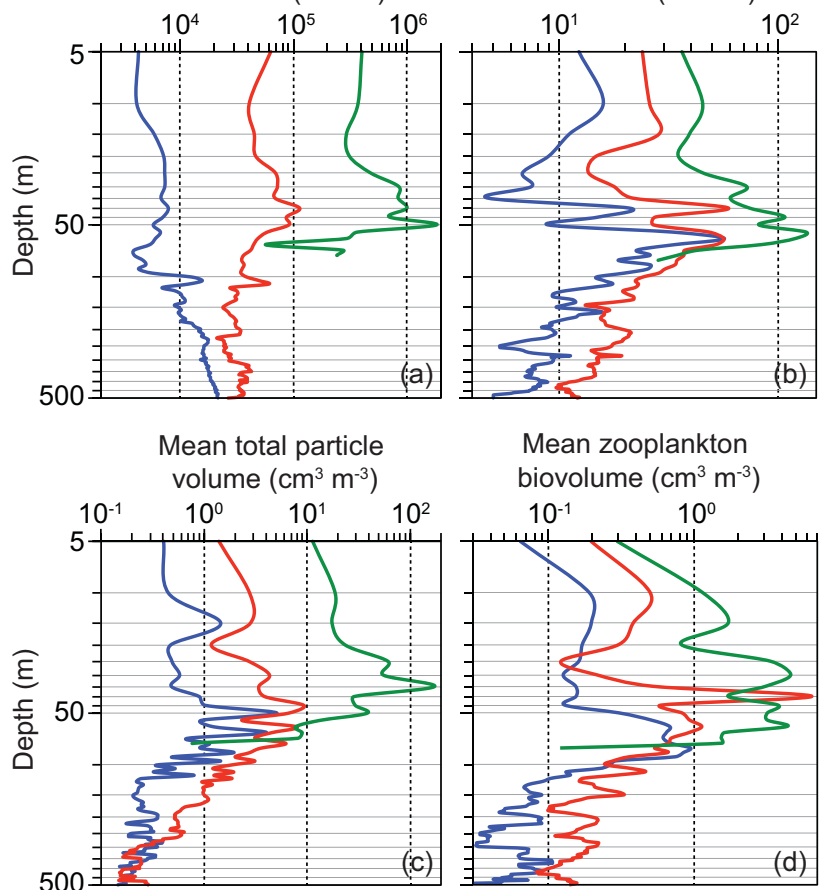

Mean zooplankton biovolume $\left(\mathrm{cm}^{3} \mathrm{~m}^{-3}\right)$

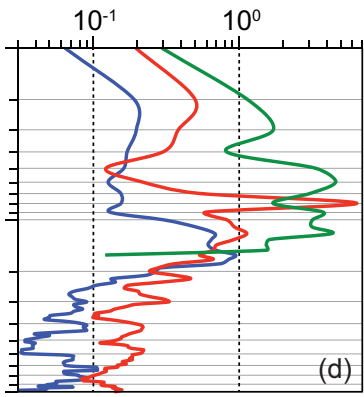

Mean chl a concentration

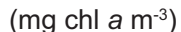

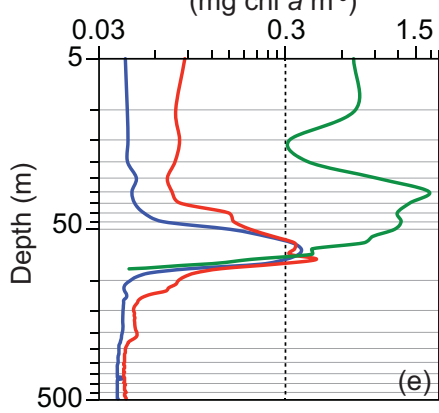

Mean beam attenuation coefficient $\left(\mathrm{m}^{-1}\right)$

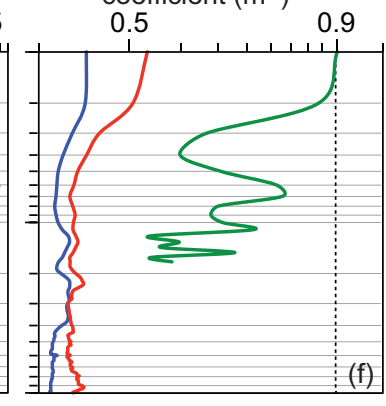

Shelf $\quad$ Slope $\longrightarrow$ Basin

Fig. 2. Mean vertical profiles of total particle abundance (a), total zooplankton abundance (b), total particle volume (c), and total zooplankton biovolume (d), as measured with the Underwater Vision Profiler deployed across the shelf $(<100 \mathrm{~m})$, slope $(100$ $1000 \mathrm{~m})$ and basin $(>1000 \mathrm{~m})$ areas of southeast Beaufort Sea in July-August 2009 (Fig. 1). The bottom panels present the mean vertical profiles of chlorophyll $a$ concentration (e) and beam attenuation coefficient (f) as recorded in the same regions and smoothed over $5 \mathrm{~m}$ depth.

For comparisons with the UVP and ZooScan biovolume datasets, the abundance of copepods (copepodites only, including adults) obtained from manual counts was converted into volume units by assimilating the body shape of a copepod to an ellipsoid for the prosome and to a cylinder for the urosome (Mauchline, 1998). Biovolume estimates based on the ellipsoid-cylinder combination were further corrected for body parts not taken into account by this method (e.g. legs, furca, antennae) using a correction factor of 1.2-1.7 depending on the average areal ratio of the supplementary parts to the mean prosome and/or urosome area. This enabled a more coherent estimation of copepod ESD for comparison with the imaging systems that use the best fitting ellipse of a given organism to calculate the ESD (Gorsky et al., 2010). Hence, the apparent ESDs presented here should be regarded as maximum values, as they correspond to the EBv. Mean lengths, widths and ratios of body parts of Arctic copepods were obtained from the historical collection of copepod measurements from the taxonomic laboratory of L. Fortier (Laval University, Canada). Missing measurements were gathered from the global literature, as cited in the online databases of Razouls et al. (2005-2011) and Appeltans et al. (2011). No morphometric estimates were attempted on zooplankton else than copepods due to uncertainties on the average body measurements of the other groups.

The size distributions and power-law relationships between abundance/biovolume and size of zooplankton from the vertical net tow datasets (i.e. ZooScan and manual counts/morphometric estimates) were calculated the same way as for the UVP5 dataset (see previous section).

\section{Results}

\subsection{Underwater Vision Profiler: magnitude and distribution of particles and zooplankton across the Mackenzie Shelf in late summer 2009}

Mean total particle $(>100 \mu \mathrm{m})$ abundance and volume recorded with the UVP5 in the surface layer $(\geq 50 \mathrm{~m})$ of southeast Beaufort Sea in July-August 2009 exhibited a decline of ca. 2 orders of magnitude when progressing from the shelf toward the basin (Fig. 2a, c). Over the shelf, maximum and minimum particle concentrations were observed around 40-50 $\mathrm{m}$ and 60-65 $\mathrm{m}$ depth, respectively (Fig. 2a). Maximum and minimum particle volumes across the three regions (Fig. 2c) corresponded roughly to patterns in total particle abundance (Fig. 2a) and in chl $a$ (Fig. 2e). Mean chl $a$ concentration over the shelf was low $\left(\sim 1.5 \mathrm{mg} \mathrm{chl} a \mathrm{~m}^{-3}\right.$ in the SCM between 30-50 m), but remained higher than values measured for the slope and basin regions $\left(\sim 0.3 \mathrm{mg} \mathrm{chl} a \mathrm{~m}^{-3}\right.$ between 50 and $80 \mathrm{~m}$ ) (Fig. 2e). Mean chl $a$ concentration and beam attenuation coefficient were also relatively high in the top $10 \mathrm{~m}$ over the shelf (Fig. 2e, f). Maximum abundance and biovolume of zooplankton were detected between 30 and $70 \mathrm{~m}$ depth (Fig. 2b, d). This interval appears to correspond to the most active water layer in terms of total particle concentration and primary production during the study period.

The spike-like increase in particle abundance just below $70 \mathrm{~m}$ on the shelf (Fig. 2a) was symptomatic of a widespread benthic nepheloid layer (BNL) comprised of small particles (Fig. 2c). The presence of a BNL over the shelf was 

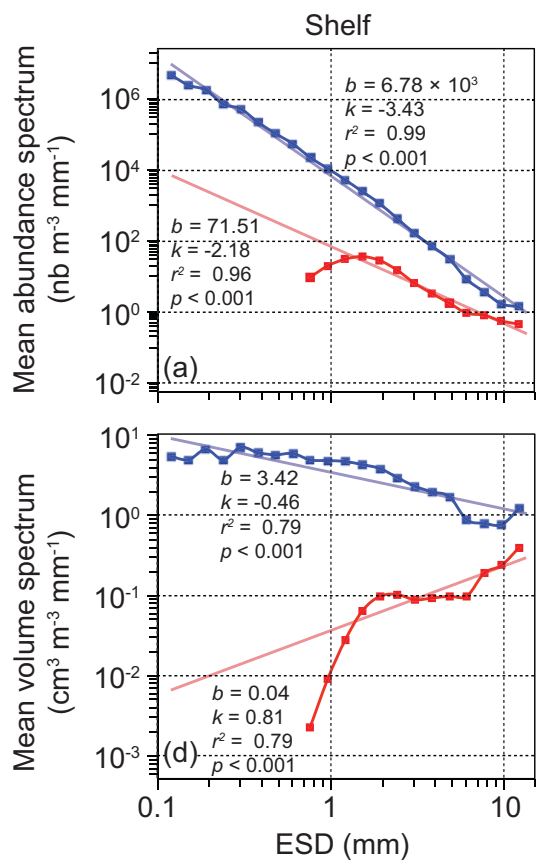
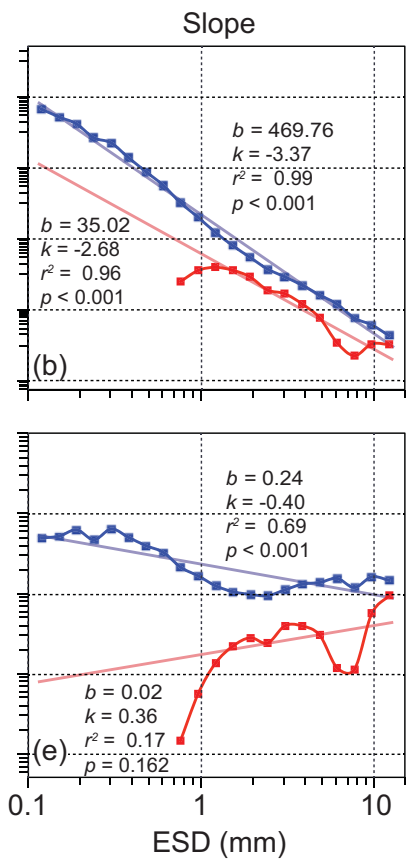
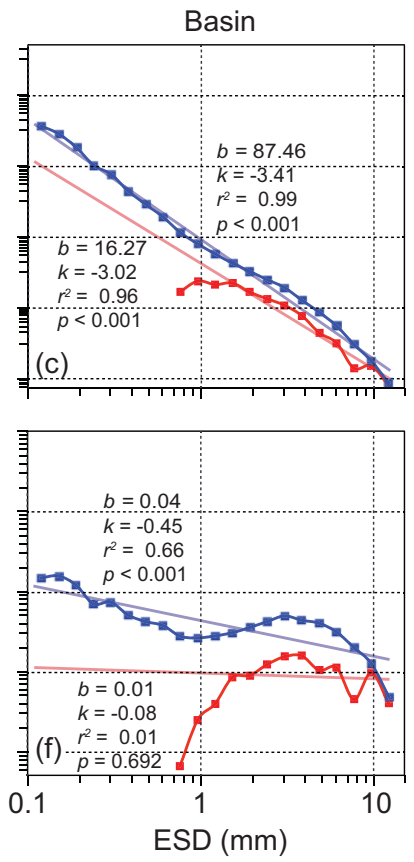

$\longrightarrow$ Total particles (living and non-living) —-Total zooplankton

Fig. 3. Mean size spectra of abundance $(\mathbf{a}-\mathbf{c})$ and volume $(\mathbf{d}-\mathbf{f})$ of total particles and total zooplankton as measured with the Underwater Vision Profiler deployed across the shelf $(<100 \mathrm{~m})$, slope $(100-1000 \mathrm{~m})$, and basin $(>1000 \mathrm{~m})$ regions of southeast Beaufort Sea in JulyAugust 2009 (Fig. 1). The $b$ and $k$ values correspond, respectively, to the constants and scaling exponents (slopes in a log-log form) of the power-law equations $\left(n=b d^{k}\right)$ derived from the normalized particle size distributions (see Sect. 2.2 for details). The power-law relationships for total particles were calculated using the full range of 0.1-12 $\mathrm{mm}$ (expressed in equivalent spherical diameter, ESD), whereas the equations for zooplankton were calculated using only the organisms $>1 \mathrm{~mm}$ ESD because of the loss in the efficiency of detection in the low end $(\leq 1 \mathrm{~mm}$ ESD) of the zooplankton size spectrum. The percent contributions of living particles to total particles as estimated with the idealized power-law equations are presented in Fig. 4.

supported by the slight increase of beam attenuation coefficient around $70-75 \mathrm{~m}$ depth (Fig. 2f). Mean particle abundance and volume over the slope peaked around 40$50 \mathrm{~m}$. While total particle abundance was relatively stable throughout the water column over the slope, particle volume decreased rapidly with increasing depth past its maximum (Fig. 2a, c). Contrastingly, particle abundance increased with increasing depth in the basin region (Fig. 2a), whereas volume in this area did not vary much (Fig. 2c).

The fit of a power-law model to the measured particle size distribution (calculated using the full ESD range of $0.1-12 \mathrm{~mm}$ ) was statistically significant both for the abundance $\left(r^{2}=0.99, p<0.0001\right)$ and volume $\left(r^{2}=0.66-0.79\right.$, $p<0.0001$ ) spectra (Fig. 3). Overall, the power-law fits were less robust for the volume size-spectra than for the abundance spectra. The exponent $(k)$ of the normalized size spectra of total particle abundance and particle volume remained relatively similar, whereas $k$ values in the size distribution of zooplankton abundance and biovolume both decreased with increasing distance from shore (Fig. 3). Zooplankton abundance and biovolume estimated with the UVP5 decreased, respectively, from $\sim 84$ to $\sim 9$ individuals (ind.) $\mathrm{m}^{-3}$ and from $\sim 2.5$ to $\sim 0.1 \mathrm{~cm}^{3} \mathrm{~m}^{-3}$ across the inshore-offshore gradient (Table 2). Such values were likely minimum estimates as zooplankton $\leq 1 \mathrm{~mm}$ ESD were not accurately quantified by the UVP5, as seen in Fig. 3 Accordingly, the power-law models were fitted to the zooplankton size spectra only for organisms $>1 \mathrm{~mm}$ ESD. The power-law equations presented in Fig. 3 enabled us to calculate the idealized contributions of planktonic particles to the total particle inventory in each size-class of the full ESD range of 0.1-12 mm (Fig. 4). These estimations revealed that living particles accounted for an increasingly large proportion of total particles from the shelf to the basin (e.g. $<1 \%$ over the shelf vs. $\sim 15 \%$ in the basin for particles $<1 \mathrm{~mm}$ ) and as the size of particles was increasing (up to $\sim 55 \%$ for $12 \mathrm{~mm}$ particles in the basin) (Fig. 4).

The zooplankton identified with the UVP5 comprised 6 major groups: protozoans, copepods, appendicularians (i.e. bodies and houses), chaetognaths, ctenophores, and other gelatinous organisms (Fig. 5, Table 2). A last category included objects $(>600 \mu \mathrm{m})$ that could have been zooplankton, but that could not be recognized with confidence. These objects were grouped as unidentified particles and contained both detrital aggregates and living organisms. Copepods 
Table 2. Abundance and biovolume of zooplankton groups (mean $\pm \mathrm{SE}$ and percent contribution in brackets) as identified and measured using an Underwater Vision Profiler 5 (UVP5) connected to a CTD-rosette profiler and deployed in the shelf $(<100 \mathrm{~m})$, slope (100-1000 m) and basin $(>1000 \mathrm{~m})$ regions of southeast Beaufort Sea in July-August 2009 (Fig. 1). The data presented in this table summarize the entire UVP5 dataset comprising 154 profiles (Appendix A). The vertical distribution of each zooplankton group abundance and biovolume is presented in Fig. 5.

\begin{tabular}{llll}
\hline & Shelf abundance $\left(\right.$ ind. $\left.\mathrm{m}^{-3}\right)$ & Slope abundance (ind. $\left.\mathrm{m}^{-3}\right)$ & Basin abundance $\left(\right.$ ind. $\left.^{-3}\right)$ \\
\hline Copepods & $68.4 \pm 6.7(81.8 \% \pm 8.0 \%)$ & $20.8 \pm 2.5(81.8 \% \pm 9.9 \%)$ & $7.7 \pm 1.0(84.3 \% \pm 11.4 \%)$ \\
Appendicularians & $7.4 \pm 1.2(8.8 \% \pm 1.4 \%)$ & $1.2 \pm 0.6(4.9 \% \pm 2.2 \%)$ & $0.2 \pm 0.1(1.8 \% \pm 0.8 \%)$ \\
Chaetognaths & $0.2 \pm 0.2(0.2 \% \pm 0.2 \%)$ & $0.1 \pm 0(0.5 \% \pm 1.0 \%)$ & $<0.1(<0.1 \%)$ \\
Protozoans & $3.1 \pm 0.9(3.7 \% \pm 1.1 \%)$ & $2.3 \pm 0.4(9.1 \% \pm 1.5 \%)$ & $0.8 \pm 0.2(9.0 \% \pm 2.6 \%)$ \\
Ctenophores & $2.0 \pm 0.5(2.4 \% \pm 0.6 \%)$ & $0.2 \pm 0(0.9 \% \pm 0.2 \%)$ & $0.1 \pm 0(0.9 \% \pm 0.4 \%)$ \\
Other gelatinous & $2.6 \pm 0.5(3.1 \% \pm 0.6 \%)$ & $0.7 \pm 0.1(2.8 \% \pm 0.4 \%)$ & $0.3 \pm 0.1(3.5 \% \pm 0.06 \%)$ \\
Total & $83.7 \pm 10.0(100 \%)$ & $25.3 \pm 3.6(100 \%)$ & $9.1 \pm 1.4(100 \%)$ \\
\hline & Shelf biovolume $\left(\mathrm{mm}^{3} \mathrm{~m}^{-3}\right)$ & Slope biovolume $\left(\mathrm{mm}^{3} \mathrm{~m}^{-3}\right)$ & Basin biovolume $\left(\mathrm{mm} \mathrm{m}^{-3}\right)$ \\
\hline Copepods & $683.6 \pm 185.7(27.5 \% \pm 7.5 \%)$ & $119.9 \pm 23.7(21.7 \% \pm 4.3 \%)$ & $54.9 \pm 8.9(42.2 \% \pm 6.8 \%)$ \\
Appendicularians & $1412.4 \pm 211.9(56.8 \% \pm 8.5 \%)$ & $381.5 \pm 239.8(69.1 \% \pm 43.5 \%)$ & $35.9 \pm 17.5(27.6 \% \pm 13.5 \%)$ \\
Chaetognaths & $140.3 \pm 39.6(5.6 \% \pm 1.6 \%)$ & $34.6 \pm 10(6.3 \% \pm 1.8 \%)$ & $28.7 \pm 9.5(22.1 \% \pm 7.3 \%)$ \\
Protozoans & $3.0 \pm 1.3(0.1 \% \pm 0.1 \%)$ & $2.0 \pm 0.3(0.4 \% \pm 0.1 \%)$ & $0.8 \pm 0.2(0.6 \% \pm 0.2 \%)$ \\
Ctenophores & $7.3 \pm 6.9(0.3 \% \pm 0.3 \%)$ & $9.4 \pm 3.3(1.7 \% \pm 0.6 \%)$ & $1.0 \pm 0.7(0.8 \% \pm 0.5 \%)$ \\
Other gelatinous & $242.2 \pm 121.6(9.7 \% \pm 4.9 \%)$ & $4.5 \pm 2.2(0.8 \% \pm 0.4 \%)$ & $8.9 \pm 8.2(6.8 \% \pm 6.3 \%)$ \\
Total & $2488.8 \pm 567.0(100 \%)$ & $551.9 \pm 279.3(100 \%)$ & $130.2 \pm 45(100 \%)$ \\
\hline
\end{tabular}

dominated numerically (82-84\%) the total zooplankton assemblage across the 3 regions (Table 2). Copepods were found in all size classes from 0.7 to $10 \mathrm{~mm}$ and dominated the total abundance and biovolume up to an ESD size of 5-6 mm (Fig. 6). The total biovolume was, however, dominated by appendicularians over the shelf and slope (57-69\%, Table 2), mainly because substantial amounts of large appendicularians houses (7-12 mm ESD) were detected at all depths by the UVP5 throughout the area (Fig. 5). It should be noted that a fraction of these houses could be old discarded houses, so uncertainties remain regarding the actual contribution of living appendicularians to total biovolume. Even if not dominating, appendicularians represented also a substantial fraction (28\%) of zooplankton biovolume in the basin (Table 2).

Vertical distribution of zooplankton, as recorded with the UVP5, varied markedly among groups and regions (Fig. 5). Over the shelf, protozoans and chaetognaths decreased with increasing depth, whereas other groups generally showed an inverse pattern. Copepods exhibited maximum abundance and biovolume in the interval $50-75 \mathrm{~m}$, just below the SCM that occupied the 30-50 m layer over the shelf (Fig. 2e). Except for ctenophores, zooplankton concentration was overall low near the bottom (75-100 m) of the outer shelf (Fig. 5). Almost no ctenophore was detected beyond the shelf margin (Fig. 5e, k). Over the slope, protozoans showed maximum concentration near the shelf break around 100-300 m (Fig. 5a, g). Copepods and appendicularians over the slope were densest in the interval $25-100 \mathrm{~m}$. In the basin, appendicularian biovolume increased with depth in the top
$100 \mathrm{~m}$ and exhibited a peak in the $75-100 \mathrm{~m}$ layer (Fig. 5i). Chaetognath abundance was well distributed throughout the water column over the slope (Fig. 5c), but its marked biovolume increase in the deep Atlantic layer $(\sim 300-1000 \mathrm{~m}$, Fig. 5j) suggested the presence of particularly large organisms in that layer (up to $10 \mathrm{~mm}$ ESD, Fig. 6b, e). The abundance and biovolume of copepods were similar in the basin and slope areas, while those of other zooplankton groups were generally lower in the basin than anywhere else (Figs. 5, 6). Appendicularians, ctenophores and other gelatinous dominated the upper size range (Fig. 6). Surprisingly, protozoans were identified up to a size class of 2-3 mm (Fig. 6), suggesting the presence of large unicellular organisms throughout the study area, such as radiolarians and foraminifera.

\subsection{Vertical net tows: composition of the zooplankton assemblage and comparisons with the overlapping stations from the UVP dataset}

A total of 93 zooplankton taxa were identified by traditional taxonomic counts in the collection of samples from the $200 \mu \mathrm{m}$ mesh nets deployed across the Mackenzie Shelf in July-August 2009 (Fig. 1, Appendix A). These zooplankton taxa were classified in large groups (Table 2) in order to provide a resolution similar to that of the UVP5 dataset (Table 3). Across the shelf, slope and basin regions, copepods (i.e. nauplii and copepodites, the latter including adults) represented $77.6 \%, 94.1 \%$ and $92.4 \%$ by numbers of all 


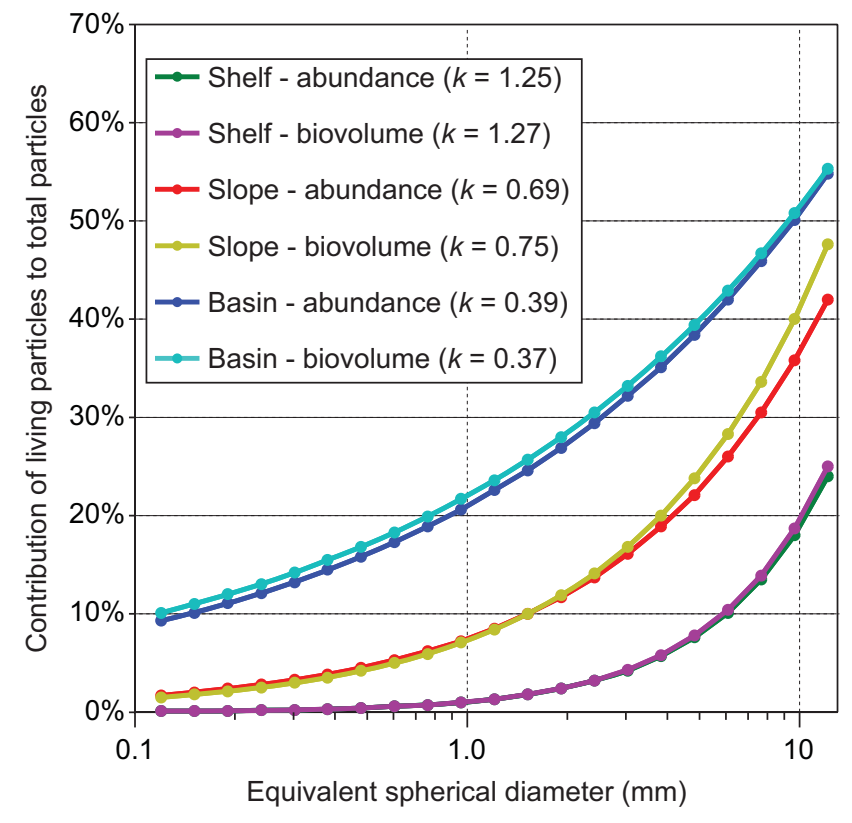

Fig. 4. Contribution of living particles (i.e. plankton) to total particle abundance and biovolume across the three target regions as estimated with the power-law equations derived from the normalized particle size distributions acquired with the Underwater Vision Profiler (Fig. 3). This figure aims at showing the idealized percentage of planktonic particulates in the total particle inventory as a function of size expressed in terms of equivalent spherical diameter (ESD). The $k$ value of each curve represents the scaling exponent of the power-law regression (i.e. slope in log-log scale) between the percent contributions of living particles and the various size classes.

the organisms collected, respectively (Table 3 ). The ratio of nauplii-to-copepodites was highest over the shelf $(0.32)$ and relatively low over the slope (0.08) and in the basin (0.06). Nauplii could be identified only to the genus level, which revealed that $\sim 75 \%$ of the community of nauplii $>200 \mu \mathrm{m}$ was (unsurprisingly) comprised of Calanus spp. (data not shown). The copepodite assemblage (including adults) was dominated by a guild of ten taxa representing $\sim 95 \%$ of all the copepodites collected (Fig. 7a). The small Oithona similis was the most abundant species ( $\sim 26-30 \%$ of the assemblage) across the 3 regions, but Pseudocalanus spp. contributed an equivalent fraction $(\sim 30 \%)$ over the shelf while representing a minor component $(\sim 6-7 \%)$ in the slope and basin assemblages. By contrast, increasing proportions of Oncaea spp. and Spinocalanus spp. (both from $<1 \%$ to $\sim 12 \%$ ) and Microcalanus spp. (from $\sim 9 \%$ to $\sim 21 \%$ ) were detected across the inshore-offshore gradient.

The approximative ESD of the most abundant copepod species present in the southeast Beaufort Sea spanned from $\sim 0.3$ up to $\sim 7 \mathrm{~mm}$ (Fig. 8 ). The mean biovolume of the total copepodite assemblage (including adults) across the shelf, slope and basin regions decreased exponentially with increasing distance from shore (Table 3). As expected, the biovolume was dominated by the large calanoid species Calanus hyperboreus $(\sim 51-58 \%)$ and $C$. glacialis $(\sim 14-$ $31 \%$ ) (Fig. 7b). The medium-sized Metridia longa accounted for a relatively low proportion of the biovolume on the slope and in the basin ( $\sim 9-12 \%)$ and was quasi-absent over the shelf $(\sim 1 \%)$. Similarly, the large Paraeuchaeta glacialis represented an increasingly important proportion (from $\sim 4 \%$ to $\sim 12 \%$ ) of the biovolume from the shelf to the basin.

The regional automatic recognition algorithm developed for ZooScan analyses enabled us to classify zooplankton from the net tow samples in 3 major groups: copepods (copepodites, including adults), appendicularians and carnivorous gelatinous (Table 4). The latter group comprised chaetognaths and medusae-like organisms that represented a relatively minor proportion of the total zooplankton identified by the ZooScan algorithm. A fourth category for detritus was also created because the net tow samples often contained a fair amount of detrital matter (Table 1). Results for the total copepod assemblage from the ZooScan analyses showed general consistency with the ones resulting from manual counts (Table 3, Table 4). The only noticeable difference was the biovolume estimated for the basin region, which was more than twice higher in ZooScan analyses than from morphometric estimates of manual counts.

For the overlapping stations (Fig. 1), the regional averages of the size distributions of copepod biovolume and abundance, as evaluated via the 3 methodologies (manual estimates, ZooScan and UVP5), showed coherent patterns co-varying in the same order of magnitude over the sizespectrum of 1-6 mm (Fig. 9). However, the loss of efficiency in detection of the UVP5 in the lower size-spectrum (Fig. 3) prevented the reliable quantification of organisms less than $\sim 1.0 \mathrm{~mm}$ ESD, whereas the ZooScan and manual estimates did quantify satisfactorily copepods down to $\sim 0.4 \mathrm{~mm}$ ESD. Every method showed an apparent maximum limit of detection around $\sim 6 \mathrm{~mm}$ ESD (Fig. 9), indicating that both the net tows and the UVP5 quantified reliably the same size-classes in the upper size spectrum ( $\geq 1 \mathrm{~mm}$ ESD). Accordingly, we calculated the parameters of the power-law equations $(n=$ $b d^{k}$ ) from the normalized copepod size distributions with the pooled datasets obtained from the 3 methods within the sizeranges where the quantification was adequate (i.e. $0.4-6 \mathrm{~mm}$ for net tow estimates and 1-6 mm for UVP5 estimates). This approach revealed that the size-spectrum slopes of both copepod abundance and biovolume gradually decreased across the shelf-basin interface (Fig. 9). Within the size-range of $1-6 \mathrm{~mm}$ ESD, where no loss of efficiency in detection was observed, all 3 methods provided statistically correlated distributions $\left(0.91>r^{2}>0.60,0.0001<p<0.01\right.$, Pearson's Model II Regression) within a proportional ratio close to 1:1 $(1.09 \pm 0.49)$. Based on manual counts and ZooScan analyses, the abundance of copepods $<1 \mathrm{~mm}$ ESD accounted for a substantial proportion of total abundance $(\sim 77-89 \%)$, but the biovolume was overwhelmingly dominated ( 93-97\%) 


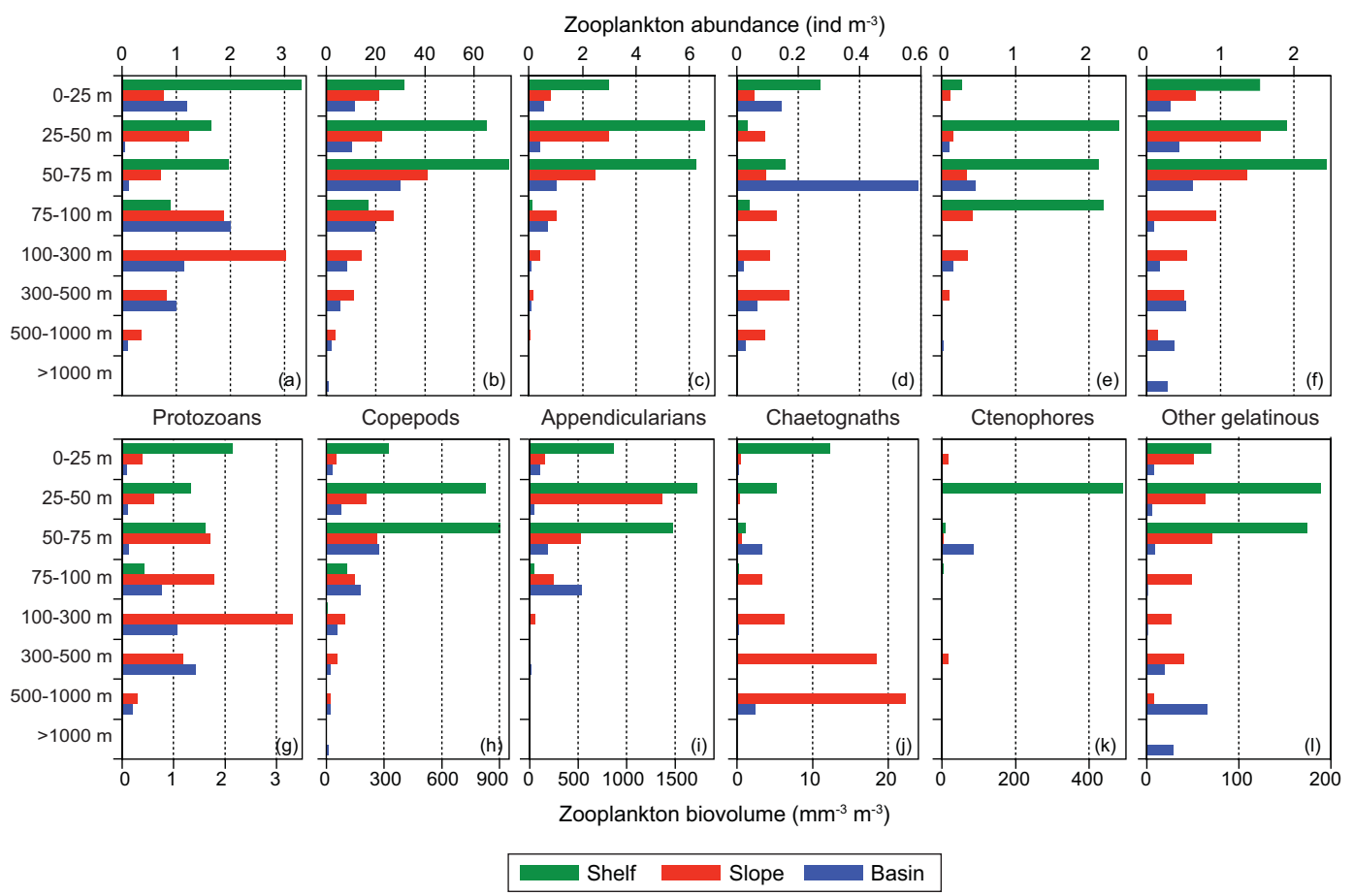

Fig. 5. Vertical distribution of zooplankton group abundance (a-f) and biovolume (g-l) as identified and measured with the Underwater Vision Profiler across the shelf $(<100 \mathrm{~m})$, slope $(100-1000 \mathrm{~m})$ and basin $(>1000 \mathrm{~m})$ areas of southeast Beaufort Sea in July-August 2009 . The zooplankton abundance and biovolume averaged for the entire water column within each of the defined regions are presented in Table 3 .
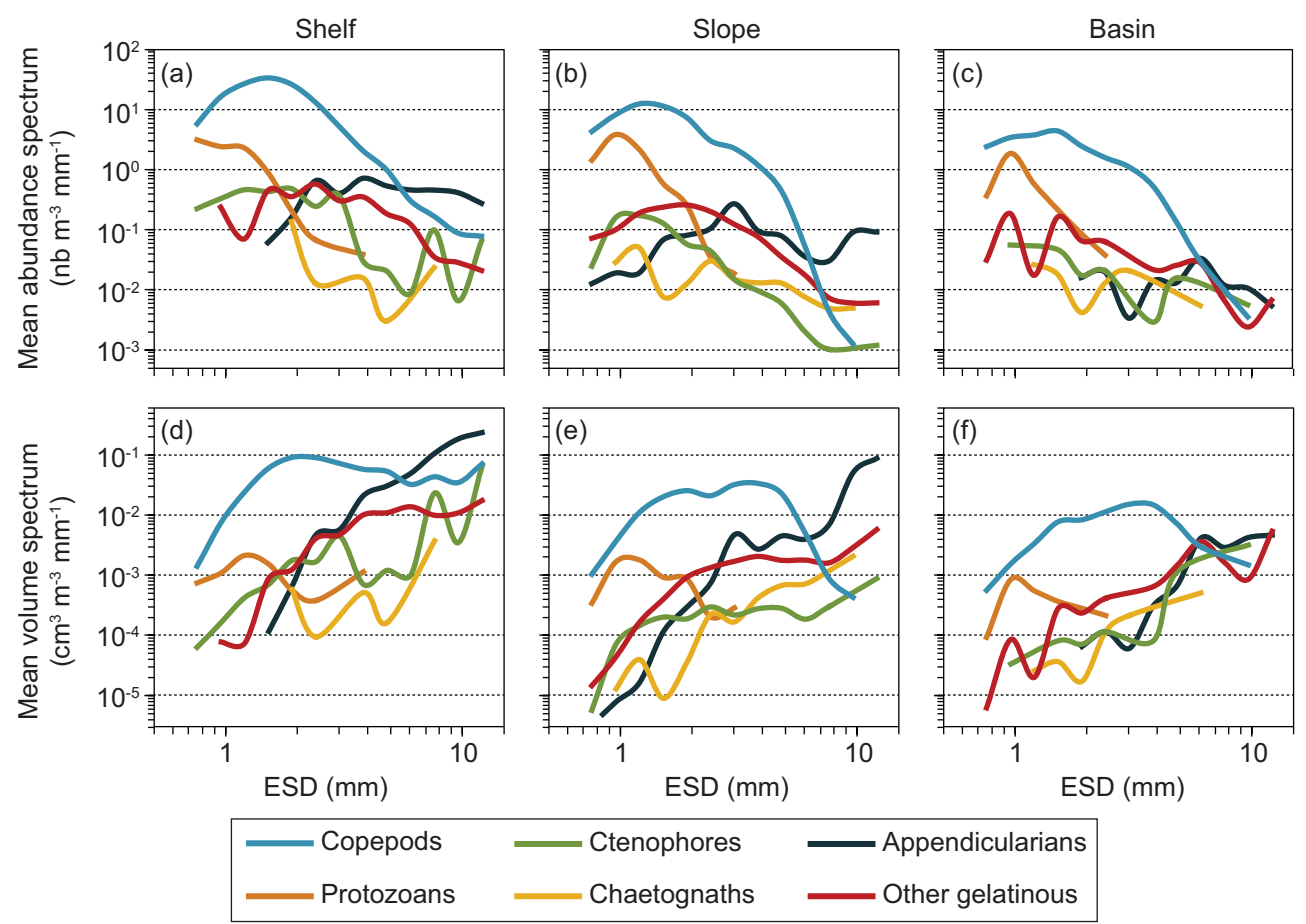

Fig. 6. Mean size spectra of abundance (a-c) and biovolume (d-f) for each zooplankton group as identified and measured with the Underwater Vision Profiler deployed across the shelf-slope-basin interface in the southeast Beaufort Sea in July-August 2009. ESD: equivalent spherical diameter. 
Table 3. Abundance of sorted zooplankton groups and biovolume of copepodites (including adults; mean \pm SE and percent contribution in brackets) as identified by traditional taxonomic counts in samples from integrated vertical net tows (bottom to surface, $200 \mu \mathrm{m}$ mesh size) conducted in the shelf $(<100 \mathrm{~m})$, slope $(100-1000 \mathrm{~m})$ and basin $(>1000 \mathrm{~m})$ regions of southeast Beaufort Sea in July-August 2009 (Fig. 1). The data presented in this table summarize the whole zooplankton net dataset comprising 29 vertical tows (Appendix A). The biovolume of copepodites was based on the morphometry of copepods for which species-specific body measurements were available (see Sect. 2.3). No morphometric estimates were attempted on other groups. N/A: not available.

\begin{tabular}{llll}
\hline & Shelf abundance (ind. $\left.\mathrm{m}^{-3}\right)$ & Slope abundance (ind. $\left.\mathrm{m}^{-3}\right)$ & ${\text { Basin abundance (ind. } \mathrm{m}^{-3} \text { ) }}$ \\
\hline Copepods (copepodites*) & $250.9 \pm 44.7(58.6 \% \pm 10.4 \%)$ & $80.2 \pm 10.2(87 \% \pm 11 \%)$ & $28.2 \pm 6.7(87.0 \% \pm 20.7 \%)$ \\
Copepods (nauplii) & $81.4 \pm 22.2(19.0 \% \pm 5.2 \%)$ & $6.8 \pm 1.1(7.3 \% \pm 1.3 \%)$ & $1.8 \pm 0.6(5.5 \% \pm 1.9 \%)$ \\
Appendicularians & $46.9 \pm 35.6(11.0 \% \pm 8.3 \%)$ & $1.0 \pm 0.2(1.0 \% \pm 0.2 \%)$ & $0.4 \pm 0.1(1.2 \% \pm 0.2 \%)$ \\
Echinoderms & $16.4 \pm 6.3(3.8 \% \pm 1.5 \%)$ & $0.3 \pm 0.1(0.3 \% \pm 0.1 \%)$ & $<0.1(<0.1 \%)$ \\
Pteropods & $15.1 \pm 5.0(3.6 \% \pm 1.2 \%)$ & $0.9 \pm 0.1(1.0 \% \pm 0.2 \%)$ & $0.6 \pm 0.3(1.9 \% \pm 0.9 \%)$ \\
Barnacles & $7.5 \pm 3.3(1.7 \% \pm 0.8 \%)$ & $0.2 \pm 0.1(0.2 \% \pm 0.1 \%)$ & $<0.1(<0.1 \%)$ \\
Protozoans & $4.7 \pm 2.7(1.1 \% \pm 0.6 \%)$ & $0.9 \pm 0.4(1.0 \% \pm 0.4 \%)$ & $0.5 \pm 0.3(1.5 \% \pm 0.9 \%)$ \\
Polychaetes & $2.1 \pm 0.9(0.5 \% \pm 0.2 \%)$ & $0.3 \pm 0.1(0.3 \% \pm 0.1 \%)$ & $0.1 \pm 0.1(0.3 \% \pm 0.2 \%)$ \\
Cnidarians & $1.7 \pm 0.4(0.4 \% \pm 0.1 \%)$ & $0.5 \pm 0.1(0.5 \% \pm 0.1 \%)$ & $0.1 \pm 0.1(0.4 \% \pm 0.2 \%)$ \\
Chaetognaths & $1.2 \pm 0.7(0.3 \% \pm 0.2 \%)$ & $0.3 \pm 0.1(0.3 \% \pm 0.1 \%)$ & $0.1 \pm 0.1(0.4 \% \pm 0.1 \%)$ \\
Ostracods & $0.2 \pm 0.1(<0.1 \%)$ & $0.9 \pm 0.2(1.0 \% \pm 0.2 \%)$ & $0.5 \pm 0.2(1.4 \% \pm 0.6 \%)$ \\
Other crustaceans & $0.2 \pm 0.1(<0.1 \%)$ & $0.2 \pm 0.1(0.2 \% \pm 0.1 \%)$ & $0.1 \pm 0.1(0.2 \% \pm 0.1 \%)$ \\
Total & $428.3 \pm 122.0(100 \%)$ & $92.4 \pm 12.7(100 \%)$ & $32.4 \pm 8.4(100 \%)$ \\
\hline & Shelf biovolume $\left(\mathrm{mm}^{3} \mathrm{~m}^{-3}\right)$ & Slope biovolume $\left(\mathrm{mm}^{3} \mathrm{~m}^{-3}\right)$ & Basin biovolume $\left(\mathrm{mm}^{3} \mathrm{~m}^{-3}\right)$ \\
\hline Copepods (copepodites*) & $404.3 \pm 69.1(\mathrm{~N} / \mathrm{A})$ & $92.5 \pm 12.1(\mathrm{~N} / \mathrm{A})$ & $23.6 \pm 2.2(\mathrm{~N} / \mathrm{A})$ \\
\hline
\end{tabular}

*Stages CI-CVI (include adults)

Table 4. Abundance and biovolume of copepods (copepodites, including adults) and appendicularians (mean \pm SE and percent contribution in brackets) as estimated with ZooScan analyses on the samples from integrated vertical net tows (bottom to surface, $200 \mu \mathrm{m}$ mesh size) conducted in the shelf $(<100 \mathrm{~m})$, slope $(100-1000 \mathrm{~m})$ and basin $(>1000 \mathrm{~m})$ regions of southeast Beaufort Sea in July-August 2009 (Fig. 1). The data presented in this table summarize the whole ZooScan dataset comprising 28 samples (Appendix A).

\begin{tabular}{llll}
\hline & Shelf abundance (ind. $\left.\mathrm{m}^{-3}\right)$ & Slope abundance (ind. $\mathrm{m}^{-3}$ ) & Basin abundance (ind. $\mathrm{m}^{-3}$ ) \\
\hline Copepods (copepodites $*)$ & $262.1 \pm 65.6(86.4 \% \pm 21.6 \%)$ & $75.3 \pm 8.1(91.6 \% \pm 9.9 \%)$ & $24.9 \pm 5(93.3 \% \pm 18.9 \%)$ \\
Appendicularians & $21.1 \pm 6.9(6.9 \% \mathrm{~m} \pm 2.3 \%)$ & $2.1 \pm 0.3(2.6 \% \pm 0.3 \%)$ & $0.6 \pm 0.1(2.2 \% \pm 0.5 \%)$ \\
Carnivorous gelatinous & $20.2 \pm 6.2(6.7 \% \pm 2.0 \%)$ & $4.7 \pm 0.7(5.8 \% \pm 0.9 \%)$ & $1.2 \pm 0.1(4.5 \% \pm 0.4 \%)$ \\
Total & $303.4 \pm 78.7(100 \%)$ & $82.2 \pm 9.1(100 \%)$ & $26.7 \pm 5.3(100 \%)$ \\
\hline & Shelf biovolume $\left(\mathrm{mm}^{3} \mathrm{~m}^{-3}\right)$ & Slope biovolume $\left(\mathrm{mm}^{3} \mathrm{~m}^{-3}\right)$ & Basin biovolume $\left(\mathrm{mm}^{3} \mathrm{~m}^{-3}\right)$ \\
\hline Copepods (copepodites $*)$ & $456.4 \pm 105.2(64 \% \pm 14.8 \%)$ & $125.6 \pm 19.9(60.5 \% \pm 9.6 \%)$ & $65.4 \pm 13.3(75.7 \% \pm 15.5 \%)$ \\
Appendicularians & $135.9 \pm 47.2(19.1 \% \pm 6.6 \%)$ & $8.3 \pm 1.2(4.0 \% \pm 0.6 \%)$ & $2.3 \pm 5.8(2.7 \% \pm 6.7 \%)$ \\
Carnivorous gelatinous & $120.4 \pm 55.2(16.9 \% \pm 7.7 \%)$ & $73.6 \pm 30.8(35.5 \% \pm 14.9 \%)$ & $18.6 \pm 6.3(21.6 \% \pm 7.4 \%)$ \\
Total & $712.6 \pm 207.5(100 \%)$ & $207.5 \pm 51.9(100 \%)$ & $86.3 \pm 25.4(100 \%)$ \\
\hline
\end{tabular}

*Stages CI-CVI (include adults)

by copepods $>1 \mathrm{~mm}$ ESD (Fig. 9). When integrated over the size-range of $1-6 \mathrm{~mm}$, the log-transformed mean abundance and biovolume of copepods estimated at each overlapping station (Fig. 1, Appendix A) with the 3 different methods showed relatively robust associations $\left(0.94>r^{2}>0.64\right)$ and significant similarities (slope close to $\sim 1$, all at $p<0.01$ ) (Fig. 10).

\section{Discussion}

\subsection{Environmental context and regional variability in the abundance, volume and size distribution of particles and mesozooplankton}

In July 2009, unusually high concentrations of old sea ice from the central Arctic pack were pushed southward in the Beaufort Sea by persistent northerly winds (CIS, 2009). The 


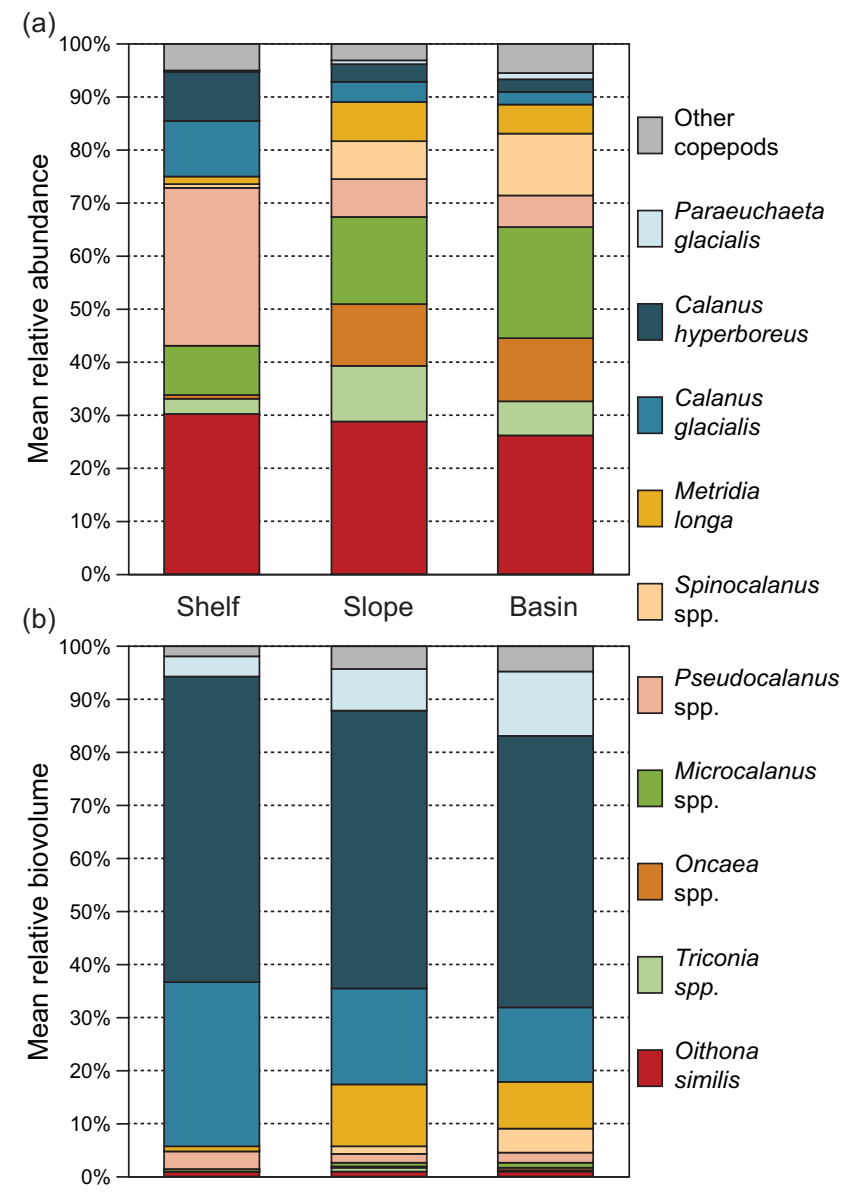

Fig. 7. Relative contribution of dominant copepod species in the total abundance (a) and biovolume (b) of copepod assemblages (copepodites only) as estimated with bottom-to-surface vertical net tows ( $200 \mu \mathrm{m}$ mesh size) conducted across the shelf-slope-basin interface in the southeast Beaufort Sea in July-August 2009. The biovolume of each species was estimated using morphometric estimates based on mean prosome and urosome lengths/widths of each copepodite stage (see Sect. 2.3 for details).

Mackenzie Shelf was generally free of ice over our sampling period, but sea ice remained abnormally close to the shelf margin located $\sim 100 \mathrm{~km}$ north off the Tuktoyaktuk Peninsula. Concurrently, the warm $\left(>8^{\circ} \mathrm{C}\right)$ plume from the Mackenzie River was observed expanding from west to east over the shelf and approximately until the ice edge (SLGO, 2011). Interestingly, no particular maximum in the total particle concentration recorded by the UVP5 was noticed near the ocean surface despite the fact that the Mackenzie River carries a substantial load of fluvial sediment (Macdonald and $\mathrm{Yu}, 2006)$. Instead, the main peak in particle concentration was linked to the occurrence of a widespread subsurface chlorophyll maximum (SCM; Martin et al., 2010) detected across the region between 30 and $70 \mathrm{~m}$ depth. The rather low background of particulate matter present down to $\sim 30 \mathrm{~m}$ supports that most terrigenous particles supplied

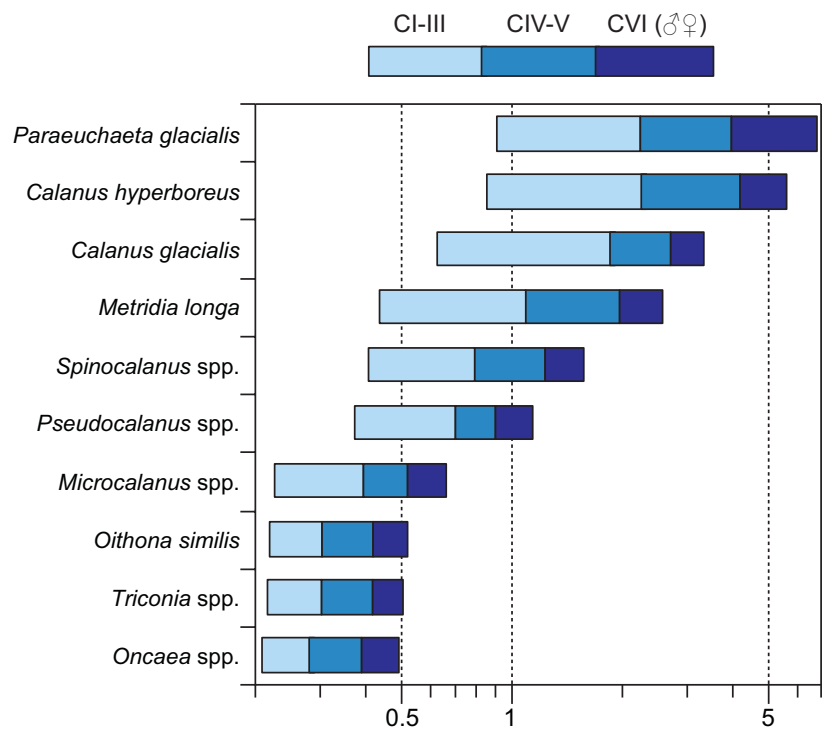

Approximative equivalent spherical diameter $(\mathrm{mm})$

Fig. 8. Approximative equivalent spherical diameter (ESD) of each dominant copepod species (Fig. 7) as estimated with morphometric relationships. The apparent ESDs presented here should be regarded as maximum values, as they correspond to the elliptical biovolume (EBv, see Sect. 2.3 for details)

by the Mackenzie River sink near the coast ( $\sim 97 \%$ of total mass; O'Brien et al., 2006). The only apparent signature of the river plume was detected in the beam attenuation coefficient and chl $a$ profiles whose signals showed visible rise above $\sim 10 \mathrm{~m}$ (Fig. 2e, f). Such a vertical pattern near the surface was the likely result of riverine waters expanding over the shelf (cf. Carmack and Macdonald, 2002) that sustained some phytoplankton biomass $\left(\sim 0.6 \mathrm{mg} \mathrm{chl} a \mathrm{~m}^{-3}\right)$ and contained small particles of the size-class $\sim 0.5-20 \mu \mathrm{m}-$ to which the beam attenuation coefficient is sensitive (Boss et al., 2001 and references therein). The fine particles that accumulated in the stratified surface layer were presumably a mixture of clay-silt material and fresh algae (cf. O'Brien et al., 2006). By contrast, the relatively high chl $a$ signal $\left(\sim 1.5 \mathrm{mg} \mathrm{chl} a \mathrm{~m}^{-3}\right)$ recorded at depth suggests that phytoplankton biomass was primarily fuelled by subsurface nutrients. The magnitude and positioning of the chl $a$ maximum indicate that the phytoplankton bloom in late-July-August 2009 in southeast Beaufort Sea was "matter of the past", as they compared well with the configuration observed toward the end of summers 2004 and 2008 (Tremblay et al., 2008; Forest et al., 2011). In fact, except for few shallow stations located over the shelf, nitrate was exhausted in the upper $\sim 40 \mathrm{~m}$ across the study area and primary production was relatively low, averaging $45 \pm 25 \mathrm{mg} \mathrm{C} \mathrm{m}^{-2} \mathrm{~d}^{-1}$ in late summer 2009 (P. Raimbault and N. Garcia, LMGEM, France, unpublished data). Nevertheless, the integrated chl $a$ biomass in the upper water column was roughly 4 -fold higher over the shelf 

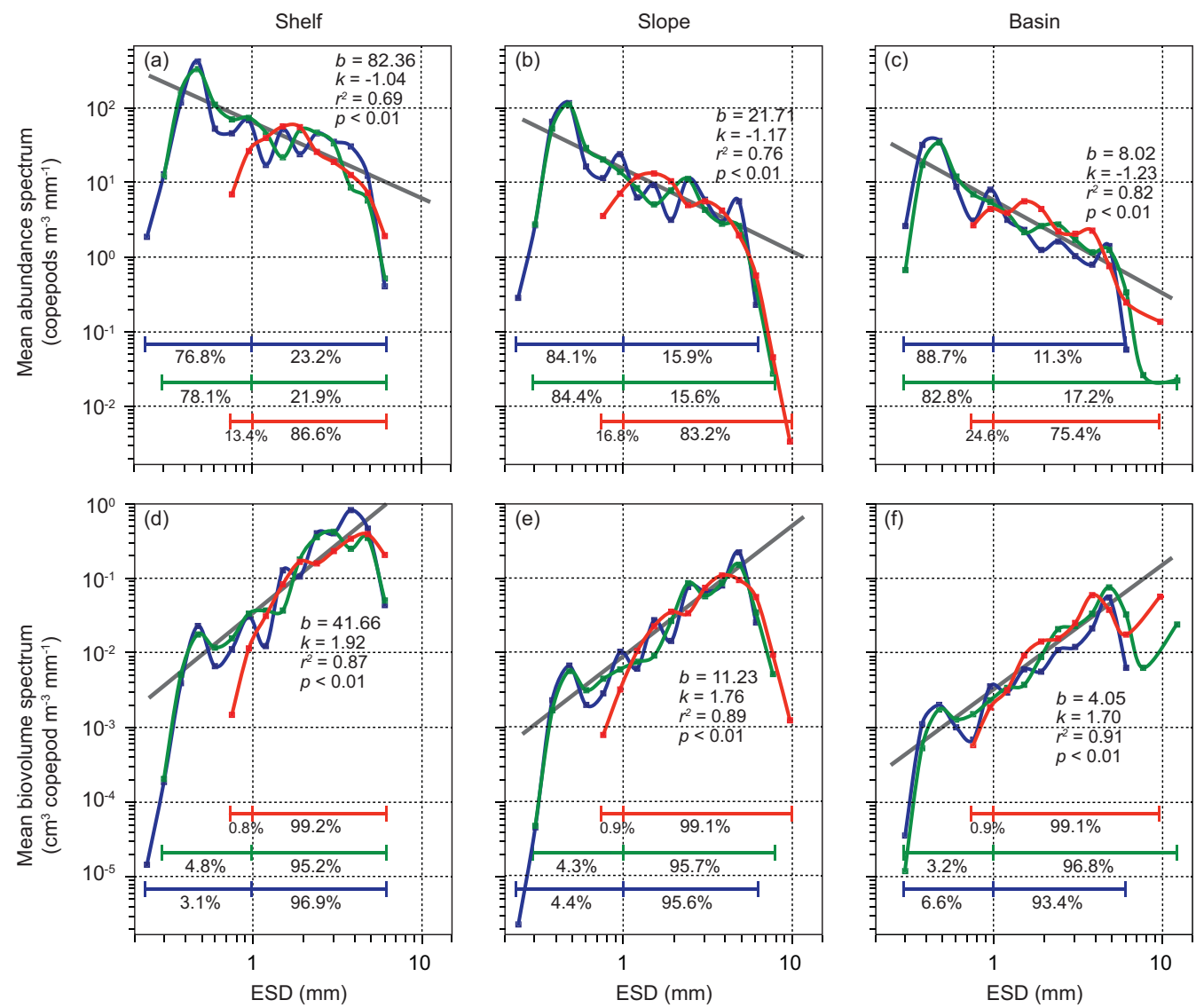

$\rightarrow$ - Net tows (manual counts and morphometric estimates) $\rightarrow$ Net tows (ZooScan counts and measurements)

- Underwater Vision Profiler counts and measurements

Fig. 9. Average size spectra of abundance (a-c) and biovolume (d-f) of the total copepod assemblage as estimated using traditional zooplankton nets (further divided into manual estimates and ZooScan measurements) and Underwater Vision Profiler deployments conducted at each of the overlapping stations (Fig. 1, Appendix A) across the shelf $(<100 \mathrm{~m})$, slope $(100-1000 \mathrm{~m})$, and basin $(>1000 \mathrm{~m})$ regions of southeast Beaufort Sea in July-August 2009. The parameters of the power-law equations $\left(n=b d^{k}\right)$ derived from size distributions were calculated with the combined datasets (see Sect. 2.3 for details). In each panel, the percent contribution of copepods $<1 \mathrm{~mm}$ and $>1 \mathrm{~mm}$ to total abundance or biovolume (i.e. sum of all size-classes) is also given according to each methodology. ESD: equivalent spherical diameter.

than beyond stations of depth $>100 \mathrm{~m}$ (Fig. 2). Nitrate is the ultimate limiting factor of primary production in the Beaufort Sea (Tremblay et al., 2008), but this does not exclude a posteriori that the presence of sea ice across the slope and basin regions could have been a local property that restrained phytoplankton growth offshore by limiting light available at the nitracline (Carmack et al., 2004; Martin et al., 2010).

Overall, zooplankton populations (as estimated with the UVP5) mirrored the inshore-offshore patterns of chl $a$ and total particle volume. The proportion of zooplankton relative to non-living particles increased with greater distance from shore and as the ESD of particles was increasing. These observations suggest that the ratio of plankton to total particles $<1 \mathrm{~mm}$ ranged from less than $1 \%$ on the shelf to $\sim 5$ $15 \%$ offshore. Then, the living fraction got rapidly more important for sizes above $\sim 1 \mathrm{~mm}$, so that non-living particles would represent $<50 \%$ of total particle inventory around 1$2 \mathrm{~cm}$ and should be virtually absent in size-classes over 4$5 \mathrm{~cm}$ (based on Fig. 4). The relatively high proportion of zooplankton vs. non-living particles in the basin compared with the shelf is in agreement with Olli et al. (2007) who observed that heterotrophs are numerous relative to phytodetritus and marine snow in the central Arctic basins. As in other oceans, most of large sinking particles in the Arctic Ocean probably settle over the continental shelf (Ashjian et al., 2005) while a strong grazing pressure offshore leaves little fresh biomass available for vertical export (Olli et al., 2007). Furthermore, the fraction of small organisms in the total plankton assemblage was increasing from the shelf to the basin since the slopes of the biovolume and abundance sizespectra were gradually more negative (Fig. 3). Although we cannot confirm that the fits derived from the UVP5 dataset 
(a)

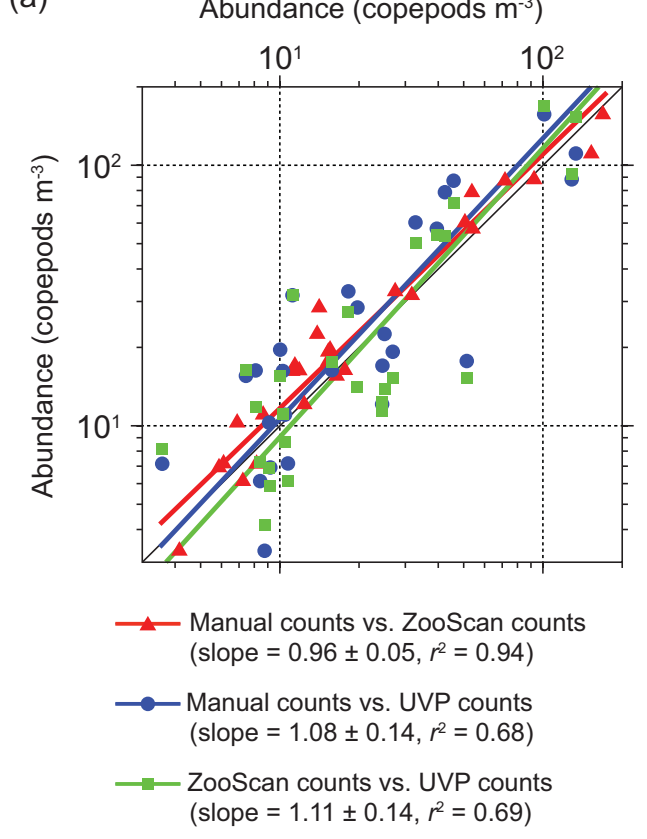

(b)

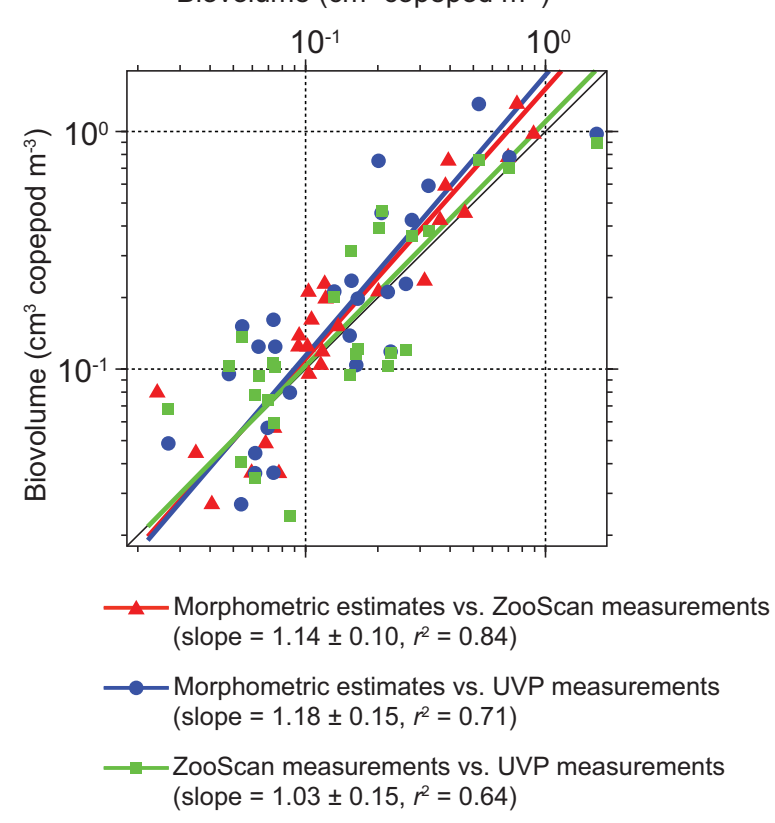

Fig. 10. Linear regressions of the log-transformed mean abundance (a) and biovolume (b) of the total copepod assemblage within the size range of 1-6 mm (equivalent spherical diameter) as estimated with traditional zooplankton net tows (further divided into manual and ZooScan estimates) and the Underwater Vision Profiler deployed at each of the overlapping stations (Fig. 1, Appendix A). Each regression presents the fit of one method ( $y$-axis) versus a second one ( $x$-axis), but no particular method was considered as the "truth" and the discussion (Sect. 4.2$)$ is aligned on a comparison between methods.

were representative of the lower size range $(<100 \mu \mathrm{m})$, they are consistent with the view that small plankton communities are a preponderant feature of the Canada Basin ( $\mathrm{Li}$ et al., 2009; Kosobokova and Hopcroft, 2010) as well as of most deep oceanic biomes (Richardson and Jackson, 2007). A food web based on small plankton might lead to more recycling and less export of organic matter to depth or up in the food chain. By contrast, we can deduce that the shelf was more favorable to large planktonic species, and thus, to more energy transfer to higher trophic levels (e.g. Frangoulis et al., 2010). However, such a simplistic distinction of the function of a given food web can be debated, since size alone is not always a direct proxy for export or retention pathway (Richardson and Jackson, 2007). Also, our study has been conducted over a limited spatial-temporal window (36 days), during a heavy ice year and toward the end of the productive season. So it is difficult to conclude on the functioning of the ecosystem in the context of an apparent quiescent period in terms of biological activity.

Nevertheless, the high-resolution CTD-UVP5 profiles conducted across the Mackenzie Shelf in late summer 2009 showed that zooplankton might have exerted an important grazing pressure on phytoplankton biomass. The vertical distribution patterns of zooplankton generally co-varied with chl $a$ concentration, a well-known feature of the world's oceans (e.g. Longhurst, 1985). However, several differences in the vertical and regional distribution patterns were observed between the specific zooplankton groups (Fig. 5). Copepods (representing $\sim 83 \%$ of the total quantity of zooplankton identified by the UVP5) showed maximum abundance and biovolume between $50-75 \mathrm{~m}$ throughout the 3 regions. This interval corresponded to the water layer located just below the SCM over the shelf, whereas it was associated with the weak chl $a$ signal offshore. Interestingly, the maximum in total zooplankton abundance (mostly copepods) on the shelf was located at $\sim 55 \mathrm{~m}$ depth, a few meters underneath the chlorophyll/particle-rich layer (Fig. 2). At this depth, a marked negative anomaly in the size-spectrum of non-zooplankton particles was observed between 0.7 and $4 \mathrm{~mm}$ ESD (down to 4 times less than expected around $1.5 \mathrm{~mm}$, not shown). These results support the conclusion of Jackson and Checkley (2011) that the base of the particlerich layer is a zone of intense particle consumption where zooplankton might act as "gatekeepers" for the vertical export of organic matter. Copepods indeed play a key role in the Arctic marine food web as one of the main regulators of vertical particle fluxes (Wassmann et al., 2003; Wexels Riser et al., 2008; Forest et al., 2011). In the Beaufort Sea, copepods may thus act as a node in the channel of organic matter by grazing within the SCM and from its underside. 
Due to the secretion of large mucous filter-houses ( $>7 \mathrm{~mm}$ ESD), appendicularians accounted for a substantial proportion ( 28-69\%) of the total zooplankton biovolume across the shelf-basin interface. Appendicularians were concentrated between 25 and $50 \mathrm{~m}$ depth, just above or within the layer occupied by the SCM, suggesting intense agglomeration of fine particles $(\sim 0.2-30 \mu \mathrm{m}$; Deibel, 1998) into gellike aggregates at these depths. Interestingly, the volume occupied by large appendicularian houses was increasing with depth until $100 \mathrm{~m}$ in the basin region (Fig. 5i). This implies that a fraction $(\sim 10-25 \%)$ of the larvacean houses produced on the shelf and slope was probably exported offshore. However, appendicularian biovolume was almost at nil values below $100 \mathrm{~m}$ depth beyond the shelf break (Fig. 5i), indicative of disaggregation and recycling of carbon-rich discarded larvacean houses (Alldredge, 1976) occurring in the Pacific Halocline. The relatively high concentration of protozoans in waters between 75 and $300 \mathrm{~m}$ depth in the slope and basin regions (Fig. 5a, g) may be the sign of an important detrital processing chain prevailing in this water mass offshore. Large suspension-feeding protozoans, such as foraminifera and radiolarians, which feed opportunistically on detritus, gels and bacteria (Capriulo, 1990), are potentially good candidates to explain the occurrence of such a detritus-based food web below the euphotic zone. The off-shelf advection of particulate matter from the shelf sediment is also a potential mechanism for sustaining an active detrital pathway in intermediate waters around the Mackenzie Shelf in the southeast Beaufort Sea (Forest et al., 2008). Indeed, in both the slope and basin areas, the weak indentation in total particle abundance around $100 \mathrm{~m}$ depth was likely symptomatic of mild intermediate nepheloid layers of fine particles originating from the shelf and propagating offshore at the depth of the shelf break (Fig. 2a, c). The increasing relative proportion of large carnivores in the mesopelagic zone (i.e. chaetognaths and other gelatinous organisms compared with copepods and appendicularians) is another evidence that supports the prevalence of a multivorous network at depth (e.g. Longhurst, 1985; Stemmann et al., 2008). Finally, the absence of most zooplankton groups below $1000 \mathrm{~m}$ (Fig. 5) suggests a "diluted" food web in the deep Canada basin, as also observed by Kosobokova and Hopcroft (2010).

\subsection{Contrasting results of the zooplankton community structure as observed with the Underwater Vision Profiler and vertical net tows}

Matching results from zooplankton net tows to those of video profilers is a challenge that can be hardly overcome due to fundamental differences in their acquisition method (e.g. Remsen et al., 2004) and/or to the fact that spatial distribution of plankton is patchy at various scales (Folt and Burns, 1999). In the present study, both the UVP5 and net tow datasets revealed that copepods were the most abundant groups, but marked discrepancies could be noticed in the absolute values presented in Tables 2-4. Total copepods (i.e. nauplii and copepodites, including adults) were systematically $2-5$ times higher in counts from net tow samples than from the UVP5. This divergence was obviously linked to the methodology and it is thus important to understand the limitations of each sampling gear before comparing the datasets. First, only copepods with visible antennae can be identified by the UVP5, so there is some underestimation of copepod abundance that cannot be quantified due to this limitation. Second, the towing speed of nets and UVP5 was relatively similar (45-60 $\mathrm{m} \mathrm{min}^{-1}$ ), but zooplankton avoidance of the descendent rosette profiler cannot be excluded. Organisms could sense the pressure wave at the front of the rosette and escape the field-of-view of the camera. Third, the UVP5 is equipped with a red light system in order to reduce zooplankton phototactic behavior (Picheral et al., 2010), but the light emitted by other optical sensors might have repelled zooplankton. Hence, the difference in copepod abundance reported here could have been caused by the addition of various factors. However, our results illustrated that it was primarily due to the fact that the UVP5 did not estimate reliably the quantity of zooplankton $<1 \mathrm{~mm}$ close to the size limit of detection (Fig. 3) and that nauplii could not be identified due to their small size $(<600 \mu \mathrm{m})$.

Over the shelf, the abundance of appendicularians was also $\sim 6$ times higher based on net tow sampling than with the UVP5, but the associated error was also high (Table 3). This result was unexpected in the sense that it is commonly known that traditional net tows cannot provide reliable estimates of fragile organisms such as appendicularians. On the one hand, a large fraction of appendicularians over the shelf could have been less than $\sim 1 \mathrm{~mm}$ ESD. Such hypothesis is quite plausible since appendicularians in the surface layer of Arctic seas (mainly oikopleurids) typically average $0.26 \mathrm{~mm}$ length and show an inverse relationship between body size and abundance (Deibel and Daly, 2007). Due to their elongated "tadpole" body shape, small appendicularians (e.g. juveniles) could get caught by $200 \mu \mathrm{m}$ mesh size nets without being identified by the UVP5. On the other hand, a patchy appendicularian swarm might have simply been sampled by one of the net tows conducted over the Mackenzie Shelf. Actually, a high number ( $>5000$ ) of small bodies of Oikopleura spp. $(<1 \mathrm{~mm}$ length) were found in the net tow sample from the first shallow station $(\sim 60 \mathrm{~m})$, which has not been recorded in the UVP5 profile conducted a few hours later at that same location. This observation reinforces the fact that both methodological differences and spatial patchiness should be considered when interpreting zooplankton data from net tows and video profilers.

The abundances of chaetognaths and protozoans estimated by both the vertical net tows and the UVP5 were low but similar (Tables 2 and 3), suggesting that both approaches provided an adequate resolution of these two zooplankton groups. Protozoans identified in the net tow samples were composed exclusively of radiolarians and foraminifera, 
two amoeboid-like plankton that could comprised species $>600 \mu \mathrm{m}$ and/or form colonies, which would explain their occurrence in the UVP5 dataset. This planktonic group seems to be a ubiquitous inhabitant of the mesopelagic layer as observed across 9 marine biogeochemical provinces (Stemmann et al., 2008). Such findings highlight that protozoans are not only members of the microzooplankton sizeclass $<200 \mu \mathrm{m}$ (Calbet et al., 2008), but also important members of the mesozooplankton - thus potentially playing an unsuspected role in the "intermediate" food web. Some zooplankton groups found in the net tow samples were not identified by the UVP5 and vice-versa (Tables 2-3). For example, pteropods and ostracods were not reported by the UVP5, a weakness that needs to be corrected for future studies since these two groups can be at time important components of the Arctic marine ecosystem (Forest et al., 2011). Although here, they were apparently minor contributors to the zooplankton assemblage. Patchy spatial distributions of those groups may also be responsible for the discrepancies between the two datasets. Furthermore, it is possible that the ctenophores identified by the UVP5 were in fact cnidarians, as no ctenophore was found in net tow samples. However, small comb jellies (and other fragile gelatinous organisms) could have been destroyed when towing the net in the water column, whereas larger medusae such as cnidarians $(>1-$ $2 \mathrm{~cm}$ ) might have resisted the ascent while not being resolved by the camera.

If we go beyond the main divergences between the UVP5 and net tow datasets, the information obtained when combining the two methods is actually complementary and instructive. The UVP5 enabled high spatial resolution and the recognition of fragile organisms, whereas the net tows provided high taxonomic resolution and the collection of more groups than the camera profiler was able to identify (e.g. pteropods). General patterns in the mesozooplankton community structure were also consistent between methods. In particular, all 3 methodologies (manual, ZooScan and UVP5) delivered consistent estimates of copepod biovolume (Tables 2-4), which demonstrates that copepod biomass is overall driven by large organisms (cf. Darnis et al., 2008). With an efficient resolution of the size-range $\sim 1-6 \mathrm{~mm}$ ESD for copepods (Fig. 9), the UVP5 appeared to have captured adequately the bulk biomass of the dominant calanoid copepods in terms of total biomass (i.e. C. hyperboreus, C. glacialis and M. longa; Fig. 8) that are of utmost importance for trophic transfer in the Beaufort Sea (Forest et al., 2011). In fact, the abundance and biovolume of copepods estimated at each station within the size-range of 1$6 \mathrm{~mm}$ was generally coherent even if the technical approach was different (Fig. 10). The significant inter-method relationships of copepod biovolume and abundance were robust $\left(0.94>r^{2}>0.64\right)$, which gave us confidence that the UVP5 dataset was representative of the assemblages of large copepods collected by the net tows. However, the small copepods $<1 \mathrm{~mm}$ ESD that accounted for a substantial pro-

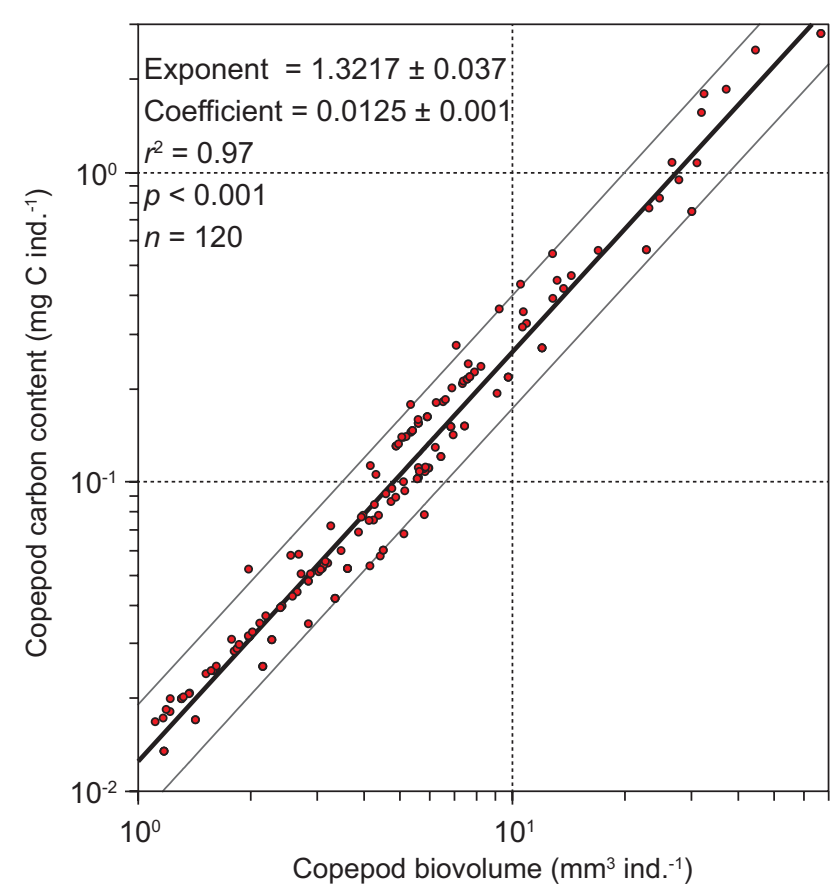

Fig. 11. Regression of the empirical carbon content of each stage of each Arctic copepod species in the size range 1-6 mm (equivalent spherical diameter) present in the Beaufort Sea against its biovolume as estimated with morphometric relationships (see Sect. 4.2 for related discussion). This regression aims at providing a specific biovolume-to-carbon conversion factor (power-law equation $\left(y=a x^{k}\right)$ where $(a)$ is the multiplier coefficient and $(k)$ is the scaling exponent) for large Arctic copepods in order to estimate most accurately the copepod biomass with the Underwater Vision Profiler 5 in the Beaufort Sea, and in the Arctic Ocean in general.

portion of the abundance ( $\sim 77-89 \%)$ obtained through net tow sampling were not efficiently identified (if not at all) by the UVP5. Still, this underscores the need of conducting traditional sampling if the determination of the fine structure of the zooplankton assemblage is the goal of a given study. But if the pursued objective is to rapidly get reliable estimates of total copepod biomass, the UVP5 appears to be a convenient approach in regions dominated by large copepod species. Therefore, we can relate the biovolume of Arctic copepods that occupy the size-range of $\sim 1-6 \mathrm{~mm}$ ESD to their carbon content, as estimated with regional carbonprosome length equations (see Forest et al., 2011 and references therein). This produces a general biovolume-to-carbon conversion factor (power-law) that can be used to estimate copepod biomass with the UVP5 in Arctic waters. This relationship is presented in Fig. 11.

The detailed composition of the zooplankton assemblage obtained with manual taxonomic counts in the present study supports generally what we know of the diversity and distribution of mesozooplankton in the Arctic Ocean. Apart from the classical notions that plankton biodiversity 
is relatively low (Table 2) and that copepod biomass is dominated by large calanoids (Fig. 7), some observations can, however, be made. Above all, the shelf environment was obviously the most active region in terms of herbivorous feeding and reproduction activities, and probably for the trophic transfer of organic matter too (as suggested in Sect. 4.1). First, the two large herbivores $C$. hyperboreus and $C$. glacialis that constitute key energy links in the Arctic food web (Falk-Petersen et al., 2009) represented alone $\sim 89 \%$ of the total copepod biomass over the shelf. Second, the small-sized Pseudocalanus spp. (which is the main prey of young stages of Polar cod, the dominant fish in the Arctic) was most abundant over the shelf, accounting for $\sim 30 \%$ by number of the total copepodite assemblage (cf. Darnis et al., 2008). Third, roughly $90 \%$ of all copepod nauplii (Calanus spp. at $\sim 75 \%$ ) collected by the $200 \mu \mathrm{m}$ mesh nets were found at stations $<100 \mathrm{~m}$ bottom depth. By contrast, the offshore assemblage was increasingly composed of carnivores, omnivores and detritivores species. For example, the large carnivore $P$. glacialis represented a gradually large proportion ( $4 \%$ to $12 \%$ ) of the copepod biomass when progressing from the shelf toward the basin. Also, the well-known omnivore M. longa (e.g. Sampei et al., 2009) was almost absent over the shelf, but accounted for $\sim 9-12 \%$ of the total copepod biomass in the two other regions. Furthermore, the small detritivore Spinocalanus spp., which is physiologically engineered to digest refractory detrital matter (Kosobokova et al., 2002), was the 5th most important species in terms of biomass beyond the shelf break. Due to their small ESD size (Fig. 8), the two latter species were likely responsible for the more negative $k$ values (spectrum slopes) of copepod abundance and biovolume recorded across the shelf-basin interface (Fig. 9), a trend comparable to what has been detected in the total zooplankton size distributions (Fig. 3). Therefore, the net tow dataset supported our previous assumption of the increasing prevalence of a high-recycling, low-productive and presumably low-export food web with greater distance from the ice-free shallow region of southeast Beaufort Sea in late summer 2009.

\section{Conclusions}

Over the Mackenzie Shelf in late summer 2009, the average phytoplankton biomass integrated in the upper water column was relatively low ( $\left.\sim 63 \mathrm{mg} \mathrm{chl} a \mathrm{~m}^{-2}\right)$, but still around 4fold higher than offshore $\left(\sim 14 \mathrm{mg} \mathrm{chl} a \mathrm{~m}^{-2}\right)$. This marked difference set the stage for the occurrence over the shelf of a diverse zooplankton community (e.g. Table 3), a dominant herbivorous food chain with a more positive biovolume size-spectrum slope (i.e. dominance of large grazers) and a relatively high secondary production (e.g. nauplii recruitment) when compared with the offshore ecosystem where multivory and recycling appeared to predominate (cf. Darnis et al., 2008). Such a shelf-basin gradient seems to be a well-defined feature of the western Arctic Ocean as a sharp latitudinal discontinuity in the abundance of marine snow and zooplankton was also previously observed between the Chukchi/Beaufort shelves and the Canada basin (Ashjian et al., 2005). However, the latter authors invoked lateral advection by the strong along-shelf current to explain the horizontal gradient, whereas our investigation suggests primarily a biological influence. Similarly, Kosobokova and Hirche (2009) surmised that regional variability in local circulation patterns was the main factor determining zooplankton biomass across Eurasian Arctic shelves, but could not exclude that food availability was also important. Therefore, a better examination of particle flux dynamics and carbon cycling in relation with the physical environment and biogeochemical conditions would be needed to determine the actual origin and fate of particulate organic matter and plankton production in the southeast Beaufort Sea in late summer 2009.

Nevertheless, our results agree well with the study of Tremblay et al. (2011) who observed high mesozooplankton recruitment on the Mackenzie Shelf in 2007-2008 and a steep gradient of productivity ( $\sim 3-4$ times difference) between the shallow shelf and the adjacent offshore area. Such a perspective indeed contrasts with Carmack and Wassmann (2006) who described the Mackenzie Shelf as an ecosystem lacking direct grazing pathways and where zooplankton populations are poorly developed. Rapid pulses and abrupt declines in ecosystem productivity induced by transient shifts in atmospheric forcing are the norm more than the exception in Arctic marine ecosystems. It is thus imperative to monitor sensitive regions such as the Beaufort Sea where a complex setup of environmental factors drives strong physical and ecological gradients. As such, the routine deployment of autonomous imaging instruments, like the Underwater Vision Profiler, can be beneficial for better understanding large-scale patterns and long-term trends in physicalbiological coupling and ecosystem function through both observations and models. Our investigation of the size distribution and mean spatial trends of large particles and zooplankton across the Mackenzie Shelf in July-August 2009 illustrated that the combination of automated imaging techniques and traditional sampling methods is a powerful approach to explore the structural diversity and functioning of Arctic ecosystems through the coastal-marine realm.

\section{Appendix A}

List of stations and metadata 
Table A1. List and metadata of oceanographic stations where sampling using an Underwater Vision Profiler 5 and traditional zooplankton nets was conducted in the southeast Beaufort Sea in July-August 2009 as part of the successive ArcticNet and Malina campaigns. Data from multiple UVP5 profiles conducted at each of the overlapping stations were averaged in order to perform comparisons with the vertical net tow dataset.

\begin{tabular}{|c|c|c|c|c|c|c|c|c|c|c|c|c|c|c|c|c|c|c|c|}
\hline Cruise & Station & Date & Time & Latitude & Longitude & Bottom & UVP5 & Zooplan & tonnet & Cruise & Station & Date & Time & Latitude & Longitude & Bottom & UVP5 & Zooplan & ton net \\
\hline & & & & & & & & & & & & & & & & & & & \\
\hline ArcticNet & 1 & 18-Jul-09 & 11:45:36 & 70.48 & 135.11 & 62 & $\mathrm{X}$ & $\mathrm{X}$ & $\mathrm{X}$ & Malina & 670 & 10-Aug-09 & $19: 26: 24$ & 69.8 & 138.44 & 172 & $\mathrm{X}$ & & \\
\hline ArcticNet & 1 & 18-Jul-09 & 12:00:00 & 70.48 & 135.12 & 62 & $\mathrm{x}$ & & & Malina & 670 & 10-Aug-09 & 21:07:12 & 69.8 & 138.44 & 174 & $\mathrm{x}$ & & \\
\hline ArcticNet & 2 & 19-Jul-09 & 00:28:48 & 70.66 & 135.64 & 148 & $\mathrm{x}$ & $\mathrm{X}$ & $\mathrm{X}$ & Malina & 670 & 10-Aug-09 & 22:48:00 & 69.8 & 138.43 & 173 & $\mathrm{X}$ & & \\
\hline ArcticNet & 11 & 19-Jul-09 & $06: 14: 24$ & 70.74 & 135.56 & 363 & $\mathrm{x}$ & $\mathrm{X}$ & $\mathrm{X}$ & Malina & 660 & 11-Aug-09 & 00:57:36 & 69.99 & 138.65 & 268 & $\mathrm{x}$ & & \\
\hline ArcticNet & 11 & 19-Jul-09 & 08:24:00 & 70.74 & 135.54 & 363 & $\mathrm{x}$ & & & Malina & 660 & 11-Aug-09 & 03:21:36 & 69.97 & 138.64 & 260 & $\mathrm{X}$ & & \\
\hline ArcticNet & 3 & 19-Jul-09 & 12:57:36 & 70.71 & 135.8 & 400 & $\mathrm{x}$ & $\mathrm{X}$ & $\mathrm{X}$ & Malina & 650 & 11-Aug-09 & 05:31:12 & 70.17 & 138.91 & 374 & $\mathrm{X}$ & & \\
\hline ArcticNet & 14 & 20-Jul-09 & $00: 28: 48$ & 70.58 & 135.95 & 94 & $\mathrm{x}$ & $\mathrm{X}$ & $\mathrm{X}$ & Malina & 640 & 11-Aug-09 & 07:40:48 & 70.34 & 139.15 & 564 & $\mathrm{x}$ & $\mathrm{x}$ & $\mathrm{X}$ \\
\hline ArcticNet & 15 & 20-Jul-09 & 06:28:48 & 70.65 & 135.93 & 294 & $\mathrm{x}$ & $\mathrm{X}$ & $\mathrm{X}$ & Malina & 630 & 11-Aug-09 & 09:07:12 & 70.53 & 139.38 & 840 & $\mathrm{x}$ & & \\
\hline ArcticNet & 17 & 20-Jul-09 & 12:57:36 & 70.61 & 136.47 & 730 & $\mathrm{x}$ & $\mathrm{X}$ & $\mathrm{X}$ & Malina & 610 & 11-Aug-09 & 14:24:00 & 70.8 & 139.6 & 1823 & $\mathrm{X}$ & & \\
\hline ArcticNet & 4 & 21-Jul-09 & $02: 38: 24$ & 70.76 & 136.02 & 688 & $\mathrm{x}$ & $\mathrm{X}$ & $\mathrm{X}$ & Malina & 620 & 11-Aug-09 & 22:48:00 & 70.67 & 139.63 & 1538 & $\mathrm{X}$ & & \\
\hline ArcticNet & 10 & 21-Jul-09 & $12: 43: 12$ & 70.79 & 135.53 & 432 & $\mathrm{x}$ & $\mathrm{X}$ & $\mathrm{X}$ & Malina & 630 & 12-Aug-09 & 00:57:36 & 70.53 & 139.37 & 840 & $\mathrm{X}$ & & \\
\hline ArcticNet & $\mathrm{I}-09$ & 21-Jul-09 & $21: 50: 24$ & 70.82 & 134.55 & 73 & $\mathrm{x}$ & & & Malina & 640 & 12-Aug-09 & 02:52:48 & 70.34 & 139.14 & 573 & $\mathrm{X}$ & & \\
\hline ArcticNet & 23 & 22-Jul-09 & 00:57:36 & 70.9 & 134.27 & 82 & $\mathrm{x}$ & $\mathrm{X}$ & $\mathrm{X}$ & Malina & 760 & 12-Aug-09 & $13: 55: 12$ & 70.55 & 140.8 & 579 & $\mathrm{X}$ & & \\
\hline ArcticNet & 22 & 22-Jul-09 & 07:40:48 & 70.82 & 134.51 & 72 & $\mathrm{x}$ & $\mathrm{X}$ & $\mathrm{X}$ & Malina & 760 & 12-Aug-09 & $15: 21: 36$ & 70.55 & 140.8 & 560 & $\mathrm{x}$ & & \\
\hline ArcticNet & 21 & 22-Jul-09 & 16:33:36 & 71.02 & 134.63 & 337 & $\mathrm{x}$ & $\mathrm{X}$ & & Malina & 760 & 12-Aug-09 & 16:48:00 & 70.55 & 140.79 & 566 & $\mathrm{x}$ & & \\
\hline ArcticNet & 18 & 23-Jul-09 & 01:12:00 & 70.88 & 135.36 & 495 & $\mathrm{x}$ & $\mathrm{X}$ & $\mathrm{X}$ & Malina & 760 & 12-Aug-09 & 19:12:00 & 70.54 & 140.78 & 644 & $\mathrm{X}$ & & \\
\hline ArcticNet & 8 & 23-Jul-09 & 07:40:48 & 70.92 & 135.86 & 782 & $\mathrm{x}$ & $\mathrm{X}$ & $\mathrm{X}$ & Malina & 770 & 12-Aug-09 & 23:02:24 & 70.35 & 140.81 & 223 & $\mathrm{x}$ & & \\
\hline ArcticNet & 20 & 23-Jul-09 & $15: 50: 24$ & 71.02 & 135.35 & 645 & $\mathrm{x}$ & $\mathrm{X}$ & $\mathrm{X}$ & Malina & 780 & 13-Aug-09 & $01: 55: 12$ & 70.15 & 140.81 & 49 & $\mathrm{x}$ & & \\
\hline ArcticNet & 16 & 24-Jul-09 & 14:09:36 & 70.8 & 136.66 & 1084 & $\mathrm{x}$ & $\mathrm{X}$ & $\mathrm{X}$ & Malina & 780 & 13-Aug-09 & 03:36:00 & 70.15 & 140.8 & 50 & $\mathrm{x}$ & & \\
\hline ArcticNet & 6 & 25-Jul-09 & 06:57:36 & 70.94 & 136.43 & 1024 & $\mathrm{x}$ & $\mathrm{X}$ & $\mathrm{X}$ & Malina & 345 & 14-Aug-09 & 16:19:12 & 71.33 & 132.56 & 479 & $\mathrm{x}$ & & \\
\hline ArcticNet & 7 & 25-Jul-09 & $14: 24: 00$ & 70.99 & 136.13 & 1018 & $\mathrm{x}$ & $\mathrm{X}$ & $\mathrm{X}$ & Malina & 345 & 14-Aug-09 & $18: 14: 24$ & 71.34 & 132.59 & 502 & $\mathrm{x}$ & & \\
\hline ArcticNet & M-09 & 26-Jul-09 & 02:52:48 & 70.74 & 135.92 & 583 & $\mathrm{x}$ & $\mathrm{X}$ & $\mathrm{X}$ & Malina & 345 & 14-Aug-09 & 20:24:00 & 71.35 & 132.61 & 517 & $\mathrm{x}$ & & \\
\hline ArcticNet & 13 & 27-Jul-09 & 03:50:24 & 70.5 & 135.67 & 66 & $\mathrm{x}$ & $\mathrm{X}$ & $\mathrm{X}$ & Malina & 345 & 14-Aug-09 & $22: 19: 12$ & 71.35 & 132.61 & 530 & $\mathrm{x}$ & & \\
\hline ArcticNet & 12 & 27-Jul-09 & 14:09:36 & 70.64 & 135.1 & 61 & $\mathrm{X}$ & $\mathrm{X}$ & $\mathrm{X}$ & Malina & 345 & 15-Aug-09 & $00: 28: 48$ & 71.35 & 132.62 & 519 & $\mathrm{x}$ & $\mathrm{X}$ & $\mathrm{X}$ \\
\hline Malina & 390 & 31-Jul-09 & 21:07:12 & 70.18 & 133.56 & 58 & $\mathrm{x}$ & & & Malina & 345 & 15-Aug-09 & 02:24:00 & 71.36 & 132.62 & 520 & $\mathrm{x}$ & & \\
\hline Malina & 390 & 31-Jul-09 & $23: 02: 24$ & 70.18 & 133.57 & 40 & $\mathrm{x}$ & & & Malina & 345 & 15-Aug-09 & $04: 19: 12$ & 71.35 & 132.61 & 524 & $\mathrm{x}$ & & \\
\hline Malina & 390 & 1-Aug-09 & 00:28:48 & 70.18 & 133.58 & 43 & $\mathrm{x}$ & & & Malina & 345 & 15-Aug-09 & $06: 14: 24$ & 71.36 & 132.61 & 536 & $\mathrm{X}$ & & \\
\hline Malina & 689 & 1-Aug-09 & $12: 28: 48$ & 69.49 & 137.94 & 52 & $\mathrm{x}$ & & & Malina & 345 & 15-Aug-09 & 08:09:36 & 71.36 & 132.61 & 539 & $\mathrm{x}$ & & \\
\hline Malina & 690 & 1-Aug-09 & $15: 07: 12$ & 69.48 & 137.93 & 51 & $\mathrm{x}$ & & & Malina & 345 & 15-Aug-09 & $10: 19: 12$ & 71.35 & 132.59 & 519 & $\mathrm{x}$ & & \\
\hline Malina & 690 & 1-Aug-09 & 16:48:00 & 69.47 & 137.95 & 53 & $\mathrm{x}$ & & & Malina & 345 & 15-Aug-09 & $12: 14: 24$ & 71.36 & 132.58 & 525 & $\mathrm{x}$ & & \\
\hline Malina & 690 & 1-Aug-09 & 20:24:00 & 69.49 & 137.94 & 55 & $\mathrm{x}$ & & & Malina & 345 & 15-Aug-09 & 14:24:00 & 71.37 & 132.69 & 559 & $\mathrm{X}$ & & \\
\hline Malina & 680 & 2-Aug-09 & $16: 48: 00$ & 69.61 & 138.21 & 120 & $\mathrm{x}$ & & & Malina & 345 & 15-Aug-09 & $16: 19: 12$ & 71.38 & 132.72 & 612 & $\mathrm{x}$ & & \\
\hline Malina & 680 & 2-Aug-09 & 19:12:00 & 69.61 & 138.22 & 122 & $\mathrm{x}$ & & & Malina & 345 & 15-Aug-09 & $18: 28: 48$ & 71.39 & 132.66 & 602 & $\mathrm{x}$ & & \\
\hline Malina & 680 & 2-Aug-09 & 20:52:48 & 69.61 & 138.22 & 124 & $\mathrm{x}$ & & & Malina & 345 & 15-Aug-09 & 20:24:00 & 71.41 & 132.64 & 580 & $\mathrm{X}$ & & \\
\hline Malina & 680 & 2-Aug-09 & 22:48:00 & 69.61 & 138.24 & 124 & $\mathrm{x}$ & & & Malina & 345 & 15-Aug-09 & $22: 19: 12$ & 71.42 & 132.62 & 619 & $\mathrm{x}$ & & \\
\hline Malina & 260 & 4-Aug-09 & 22:04:48 & 71.27 & 130.61 & 54 & $\mathrm{x}$ & $\mathrm{X}$ & $\mathrm{X}$ & Malina & 345 & 16-Aug-09 & 00:28:48 & 71.42 & 132.59 & 625 & $\mathrm{x}$ & & \\
\hline Malina & 260 & 5-Aug-09 & 00:00:00 & 71.27 & 130.6 & 59 & $\mathrm{x}$ & & & Malina & 345 & 16-Aug-09 & 02:24:00 & 71.41 & 132.58 & 602 & $\mathrm{X}$ & & \\
\hline Malina & 250 & 5-Aug-09 & 04:19:12 & 71.47 & 130.7 & 219 & $\mathrm{x}$ & & & Malina & 345 & 16-Aug-09 & 04:19:12 & 71.43 & 132.61 & 654 & $\mathrm{X}$ & & \\
\hline Malina & 240 & 5-Aug-09 & $06: 14: 24$ & 71.67 & 130.74 & 462 & $\mathrm{x}$ & $\mathrm{X}$ & $\mathrm{X}$ & Malina & 570 & 17-Aug-09 & 10:48:00 & 70.21 & 137.26 & 55 & $\mathrm{X}$ & & \\
\hline Malina & 230 & 5-Aug-09 & 08:09:36 & 71.87 & 130.84 & 702 & $\mathrm{x}$ & & & Malina & 560 & 17-Aug-09 & $12: 14: 24$ & 70.39 & 137.48 & 400 & $\mathrm{X}$ & & \\
\hline Malina & 220 & 5-Aug-09 & 10:19:12 & 72.06 & 130.89 & 890 & $\mathrm{x}$ & & & Malina & 550 & 17-Aug-09 & 14:09:36 & 70.57 & 137.71 & 1077 & $\mathrm{x}$ & & \\
\hline Malina & 220 & 5-Aug-09 & 14:09:36 & 72.05 & 130.83 & 834 & $\mathrm{x}$ & & & Malina & 540 & 17-Aug-09 & 17:16:48 & 70.75 & 137.89 & 1514 & $\mathrm{x}$ & $\mathrm{x}$ & $\mathrm{X}$ \\
\hline Malina & 220 & 5-Aug-09 & $15: 50: 24$ & 72.05 & 130.88 & 880 & $\mathrm{x}$ & & & Malina & 540 & 17-Aug-09 & 20:09:36 & 70.76 & 137.89 & 1514 & $\mathrm{x}$ & & \\
\hline Malina & 220 & 5-Aug-09 & $17: 31: 12$ & 72.05 & 130.94 & 911 & $\mathrm{x}$ & & & Malina & 540 & 17-Aug-09 & 22:04:48 & 70.76 & 137.87 & 1522 & $\mathrm{X}$ & & \\
\hline Malina & 240 & 5-Aug-09 & 22:19:12 & 71.67 & 130.73 & 465 & $\mathrm{x}$ & & & Malina & 530 & 18-Aug-09 & 04:33:36 & 70.94 & 138.15 & 1602 & $\mathrm{X}$ & & \\
\hline Malina & 240 & 6-Aug-09 & 00:28:48 & 71.67 & 130.74 & 455 & $\mathrm{x}$ & & & Malina & 430 & 18-Aug-09 & $15: 07: 12$ & 71.22 & 136.71 & 1361 & $\mathrm{X}$ & & \\
\hline Malina & 110 & 6-Aug-09 & 11:02:24 & 71.7 & 126.48 & 400 & $\mathrm{x}$ & & & Malina & 430 & 18-Aug-09 & $17: 31: 12$ & 71.2 & 136.74 & 1334 & $\mathrm{x}$ & & \\
\hline Malina & 110 & 6-Aug-09 & $15: 21: 36$ & 71.7 & 126.48 & 397 & $\mathrm{x}$ & & & Malina & 430 & 18-Aug-09 & 19:26:24 & 71.18 & 136.75 & 1300 & $\mathrm{x}$ & & \\
\hline Malina & 110 & 6-Aug-09 & 18:00:00 & 71.7 & 126.48 & 395 & $\mathrm{x}$ & & & Malina & 440 & 19-Aug-09 & $00: 14: 24$ & 71.04 & 136.46 & 1149 & $\mathrm{x}$ & & \\
\hline Malina & 120 & 6-Aug-09 & 23:02:24 & 71.57 & 126.91 & 419 & $\mathrm{x}$ & & & Malina & 450 & 19-Aug-09 & 02:24:00 & 70.86 & 136.24 & 840 & $\mathrm{x}$ & & \\
\hline Malina & 130 & 7-Aug-09 & $00: 57: 36$ & 71.43 & 127.37 & 311 & $\mathrm{X}$ & $\mathrm{X}$ & $\mathrm{X}$ & Malina & 480 & 19-Aug-09 & 07:26:24 & 70.28 & 135.75 & 60 & $\mathrm{x}$ & & \\
\hline Malina & 130 & 7-Aug-09 & 03:36:00 & 71.42 & 127.36 & 313 & $\mathrm{x}$ & & & Malina & 460 & 19-Aug-09 & $13: 40: 48$ & 70.68 & 136.05 & 468 & $\mathrm{x}$ & & \\
\hline Malina & 140 & 7-Aug-09 & 09:07:12 & 71.28 & 127.79 & 140 & $\mathrm{x}$ & & & Malina & 460 & 19-Aug-09 & $15: 50: 24$ & 70.68 & 135.99 & 434 & $\mathrm{x}$ & $\mathrm{x}$ & $\mathrm{X}$ \\
\hline Malina & 150 & 7-Aug-09 & 11:16:48 & 71.16 & 128.16 & 66 & $\mathrm{x}$ & & & Malina & 460 & 19-Aug-09 & $16: 19: 12$ & 70.68 & 135.97 & 420 & $\mathrm{x}$ & & \\
\hline Malina & 160 & 7-Aug-09 & $12: 43: 12$ & 71.05 & 128.5 & 43 & $\mathrm{x}$ & & & Malina & 460 & 19-Aug-09 & $18: 14: 24$ & 70.68 & 135.89 & 362 & $\mathrm{x}$ & & \\
\hline Malina & 170 & 7-Aug-09 & $14: 38: 24$ & 70.91 & 128.92 & 35 & $\mathrm{x}$ & & & Malina & 135 & 20-Aug-09 & 18:43:12 & 71.31 & 127.48 & 231 & $\mathrm{x}$ & & \\
\hline Malina & 170 & 7-Aug-09 & $16: 19: 12$ & 70.92 & 128.92 & 35 & $\mathrm{x}$ & & & Malina & 135 & 20-Aug-09 & 20:24:00 & 71.31 & 127.49 & 230 & $\mathrm{x}$ & & \\
\hline Malina & 170 & 7-Aug-09 & $17: 45: 36$ & 70.92 & 128.92 & 35 & $\mathrm{x}$ & & & Malina & 135 & 20-Aug-09 & 22:48:00 & 71.31 & 127.49 & 228 & $\mathrm{X}$ & & \\
\hline Malina & 150 & 7-Aug-09 & 23:02:24 & 71.16 & 128.16 & 66 & $\mathrm{x}$ & & & Malina & 135 & 21-Aug-09 & 00:28:48 & 71.31 & 127.5 & 223 & $\mathrm{X}$ & & \\
\hline Malina & 150 & 8-Aug-09 & 01:12:00 & 71.16 & 128.16 & 66 & $\mathrm{x}$ & & & Malina & 135 & 21-Aug-09 & 02:24:00 & 71.31 & 127.49 & 230 & $\mathrm{x}$ & & \\
\hline Malina & 390 & 8-Aug-09 & $11: 31: 12$ & 70.18 & 133.56 & 44 & $\mathrm{x}$ & & & Malina & 135 & 21-Aug-09 & 04:19:12 & 71.31 & 127.49 & 231 & $\mathrm{x}$ & & \\
\hline Malina & 380 & 8-Aug-09 & 13:12:00 & 70.4 & 133.61 & 60 & $\mathrm{X}$ & & & Malina & 135 & 21-Aug-09 & 06:14:24 & 71.31 & 127.5 & 228 & $\mathrm{X}$ & & \\
\hline Malina & 380 & 8-Aug-09 & $14: 52: 48$ & 70.4 & 133.6 & 63 & $\mathrm{x}$ & & & Malina & 135 & 21-Aug-09 & 08:24:00 & 71.31 & 127.49 & 227 & $\mathrm{x}$ & & \\
\hline Malina & 380 & 8-Aug-09 & 16:19:12 & 70.39 & 133.6 & 62 & $\mathrm{x}$ & & & Malina & 135 & 21-Aug-09 & 10:19:12 & 71.31 & 127.49 & 230 & $\mathrm{X}$ & & \\
\hline Malina & 370 & 8-Aug-09 & 19:12:00 & 70.6 & 133.65 & 70 & $\mathrm{x}$ & & & Malina & 135 & 21-Aug-09 & $12: 57: 36$ & 71.31 & 127.49 & 227 & $\mathrm{X}$ & & \\
\hline Malina & 360 & 8-Aug-09 & 22:04:48 & 70.8 & 133.73 & 75 & $\mathrm{x}$ & & & Malina & 135 & 21-Aug-09 & 14:24:00 & 71.31 & 127.5 & 224 & $\mathrm{X}$ & & \\
\hline Malina & 360 & 8-Aug-09 & 23:31:12 & 70.8 & 133.73 & 74 & $\mathrm{x}$ & & & Malina & 135 & 21-Aug-09 & 16:19:12 & 71.31 & 127.5 & 222 & $\mathrm{x}$ & & \\
\hline Malina & 350 & 9-Aug-09 & 04:19:12 & 70.97 & 133.73 & 90 & $\mathrm{x}$ & & & Malina & 135 & 21-Aug-09 & 18:28:48 & 71.31 & 127.49 & 227 & $\mathrm{x}$ & & \\
\hline Malina & 340 & 9-Aug-09 & $06: 28: 48$ & 71.17 & 133.83 & 575 & $\mathrm{x}$ & & & Malina & 135 & 21-Aug-09 & 20:24:00 & 71.31 & 127.5 & 227 & $\mathrm{X}$ & & \\
\hline Malina & 330 & 9-Aug-09 & 08:09:36 & 71.37 & 133.89 & 1080 & $\mathrm{x}$ & & & Malina & 135 & 21-Aug-09 & 22:48:00 & 71.31 & 127.5 & 225 & $\mathrm{x}$ & & \\
\hline Malina & 320 & 9-Aug-09 & 10:19:12 & 71.57 & 133.94 & 1159 & $\mathrm{x}$ & & & Malina & 235 & 22-Aug-09 & $08: 38: 24$ & 71.76 & 130.83 & 619 & $\mathrm{X}$ & $\mathrm{X}$ & $\mathrm{X}$ \\
\hline Malina & 310 & 9-Aug-09 & $12: 43: 12$ & 71.74 & 133.95 & 1614 & $\mathrm{x}$ & & & Malina & 235 & 22-Aug-09 & 10:48:00 & 71.76 & 130.76 & 567 & $\mathrm{X}$ & & \\
\hline Malina & 320 & 9-Aug-09 & 15:07:12 & 71.57 & 133.95 & 1160 & $\mathrm{x}$ & & & Malina & 235 & 22-Aug-09 & $12: 14: 24$ & 71.76 & 130.81 & 599 & $\mathrm{X}$ & & \\
\hline Malina & 320 & 9-Aug-09 & $17: 02: 24$ & 71.56 & 133.95 & 1141 & $\mathrm{x}$ & & & Malina & 235 & 22-Aug-09 & $14: 09: 36$ & 71.77 & 130.8 & 598 & $\mathrm{x}$ & & \\
\hline Malina & 320 & 9-Aug-09 & 18:57:36 & 71.56 & 133.95 & 1115 & $\mathrm{x}$ & & & Malina & 235 & 22-Aug-09 & $16: 19: 12$ & 71.76 & 130.83 & 617 & $\mathrm{x}$ & & \\
\hline Malina & 330 & 9-Aug-09 & 21:36:00 & 71.37 & 133.89 & 1080 & $\mathrm{x}$ & & & Malina & 235 & 22-Aug-09 & $18: 28: 48$ & 71.77 & 130.9 & 666 & $\mathrm{x}$ & & \\
\hline Malina & 340 & 9-Aug-09 & $23: 45: 36$ & 71.17 & 133.82 & 590 & $\mathrm{X}$ & & & Malina & 235 & 22-Aug-09 & 20:24:00 & 71.77 & 130.94 & 681 & $\mathrm{x}$ & & \\
\hline
\end{tabular}


Acknowledgements. We express gratitude to the officers and crew members of the CCGS Amundsen for professional and enthusiastic assistance at sea. We thank Y. Gratton and L. Prieur for crucial help in the deployment of the CTD-rosette profiler as well as to C. Marec for her diligent implication in the onboard processing of UVP5 data. We acknowledge V. Galindo, L. Létourneau and K. Lévesque for the collection of zooplankton samples with vertical net tows. We thank C. Desnos and J.-B. Romagnan for help in operating the ZooScan. Special thanks to L. Bisson-Gauthier for the validation of ZooScan vignettes. Thanks to G. Darnis, A. Marceau and B. Fortier for help in compiling copepod body measurements. We are grateful to S. Bélanger, J. Martin, J. Gagnon, A. Mignot and M. Gosselin for sharing the chlorophyll data to post-calibrate the fluorometer probe. We thank P. Guillot for the processing of CTD data. We thank M. Fortier, K. Lévesque and J. Ehn for the organization of the fieldwork and workshops. We thank S. Basedow, E. Boss and two anonymous reviewers for insightful comments that improved the initial manuscript. This study was conducted in the framework of the ArcticNet-Imperial Oil Research Collaboration and of the Malina Scientific Program. The ArcticNet Network is funded by the program of Networks of Centres of Excellence (NCE) of Canada. The Malina project is funded by the Centre National de la Recherche Scientifique (CNRS) and by the French and European Space Agencies. This work is a contribution to the research programs of Québec-Océan, ArcticNet, the Takuvik Joint U. Laval/CNRS Laboratory, Malina, to the Canada Research Chair on the Response of Marine Arctic Ecosystems to Climate Warming, and to the Canada Excellence Research Chair in Remote Sensing of Canada's New Arctic Frontier.

Edited by: E. Boss

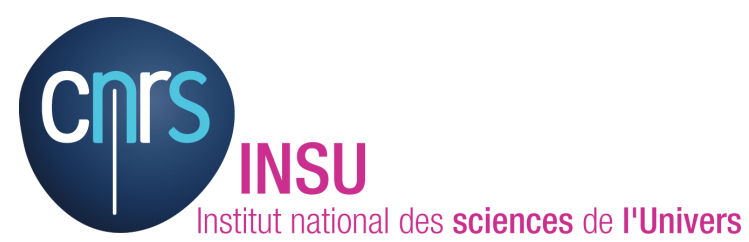

The publication of this article is financed by CNRS-INSU.

\section{References}

Alldredge, A. L.: Discarded appendicularian houses as sources of food, surface habitats, and particulate organic matter in planktonic environments, Limnol. Oceanogr, 21, 14-23, 1976.

Appeltans, W., Bouchet, P., Boxshall, G. A., Fauchald, K., Gordon, D. P., Hoeksema, B. W., Poore, G. C. B., van Soest, R. W. M., Stöhr, S., Walter, T. C., and Costello, M. J.: World Register of marine species, http://www.marinespecies.org, 2011.

Ashjian, C. J., Gallager, S. M., and Plourde, S.: Transport of plankton and particles between the Chukchi and Beaufort Seas during summer 2002, described using a Video Plankton Recorder, DeepSea Res. Pt. II, 52, 3259-3280, doi:10.1016/j.dsr2.2005.10.012, 2005.
Barber, D. G. and Hanesiak, J. M.: Meteorological forcing of sea ice concentrations in the southern Beaufort Sea over the period 1979 to 2000, J. Geophys. Res., 109, C06014, doi:10.1029/2003jc002027, 2004.

Boss, E., Twardowski, M. S., and Herring, S.: Shape of the particulate beam attenuation spectrum and its inversion to obtain the shape of the particulate size distribution, Appl. Opt., 40, 48854893, doi:10.1364/AO.40.004885, 2001.

Brugel, S., Nozais, C., Poulin, M., Tremblay, J. E., Miller, L. A., Simpson, K. G., Gratton, Y., and Demers, S.: Phytoplankton biomass and production in the southeastern Beaufort Sea in autumn 2002 and 2003, Mar. Ecol. Prog. Ser., 377, 63-77, doi:10.3354/meps07808, 2009.

Burd, A. B. and Jackson, G. A.: Particle Aggregation, Ann. Rev. Mar. Sci., 1, 65-90, doi:10.1146/annurev.marine.010908.163904, 2009.

Calbet, A.: The trophic roles of microzooplankton in marine systems, ICES J. Mar. Sci., 65, 325-331, doi:10.1093/icesjms/fsn013, 2008.

Campbell, R. G., Sherr, E. B., Ashjian, C. J., Plourde, S., Sherr, B. F., Hill, V., and Stockwell, D. A.: Mesozooplankton prey preference and grazing impact in the Western Arctic Ocean, DeepSea Res. Pt. II, 56, 1274-1289, doi:10.1016/j.dsr2.2008.10.027, 2009.

Capriulo, G. M.: Feeding-related ecology of marine protozoa, in: Ecology of marine protozoa, edited by: Capriulo, G. M., Oxford University Press, Oxford, 186-259, 1990.

Carmack, E. C. and MacDonald, R. W.: Oceanography of the Canadian Shelf of the Beaufort Sea: a setting for marine life, Arctic, 55, Suppl. 1, 29-45, 2002.

Carmack, E. and Wassmann, P.: Food webs and physicalbiological coupling on pan-Arctic shelves: Unifying concepts and comprehensive perspectives, Prog. Oceanogr., 71, 446-477, doi:10.1016/j.pocean.2006.10.004, 2006.

Carmack, E. C., Macdonald, R. W., and Jasper, S.: Phytoplankton productivity on the Canadian Shelf of the Beaufort Sea, Mar. Ecol. Prog. Ser., 277, 37-50, 2004.

CIS: Seasonal Summary for the Canadian Arctic - Summer 2009, Canadian Ice Service web site, http://www.ec.gc.ca/Publications, 2009.

Crease, J.: The acquisition, calibration and analysis of CTD data, Unesco Technical Papers in Marine Science No. 54, Report of SCOR Working Group 51, Division of Marine Sciences, UNESCO, Paris, 105 pp., 1988.

Darnis, G., Barber, D. G., and Fortier, L.: Sea ice and the onshore-offshore gradient in pre-winter zooplankton assemblages in south-eastern Beaufort Sea, J. Mar. Syst., 74, 9941011, doi:10.1016/j.jmarsys.2007.09.003, 2008.

Deibel, D.: Feeding and metabolism of Appendicularia, in: The biology of pelagic tunicates, edited by: Bone, Q., Oxford University Press, New-York, 139-159, 1998.

Deibel, D. and Daly, K.: Zooplankton Processes in Arctic and Antarctic Polynyas, in: Polynyas: Windows to the World, edited by: Smith, W. O. and Barber, D. G., Elsevier, Amsterdam, 271311, 2007.

Falk-Petersen, S., Mayzaud, P., Kattner, G., Sargent, J. R., and Fenchel, T.: Lipids and life strategy of Arctic Calanus, Mar. Biol. Res., 5, 18-39, doi:10.1080/17451000802512267, 2009. 
Folt, C. L. and Burns, C. W.: Biological drivers of zooplankton patchiness, Trends Ecol. Evol., 14, 300-305, doi:10.1016/s01695347(99)01616-x, 1999.

Forest, A., Sampei, M., Makabe, R., Sasaki, H., Barber, D., Gratton, Y., Wassmann, P., and Fortier, L.: The annual cycle of particulate organic carbon export in Franklin Bay (Canadian Arctic): Environmental control and food web implications, J. Geophys. Res., 113, C03S05, doi:10.1029/2007JC004262, 2008.

Forest, A., Tremblay, J.-É., Gratton, Y., Martin, J., Gagnon, J., Darnis, G., Sampei, M., Fortier, L., Ardyna, M., Gosselin, M., Hattori, H., Nguyen, D., Maranger, R., Vaque, D., Marrase, C., Pedros-Alio, C., Sallon, A., Michel, C., Kellogg, C., Deming, J., Shadwick, E., Thomas, H., Link, H., Archambault, P., and Piepenburg, D.: Biogenic carbon flows through the planktonic food web of the Amundsen Gulf (Arctic Ocean): A synthesis of field measurements and inverse modeling analyses, Prog. Oceanogr., 91, 410-436, doi:10.1016/j.pocean.2011.05.002, 2011.

Frangoulis, C., Psarra, S., Zervakis, V., Meador, T., Mara, P., Gogou, A., Zervoudaki, S., Giannakourou, A., Pitta, P., Lagaria, A., Krasakopoulou, E., and Siokou-Frangou, I.: Connecting export fluxes to plankton food-web efficiency in the Black Sea waters inflowing into the Mediterranean Sea, J. Plankton Res., 32, 1203-1216, doi:10.1093/plankt/fbq010, 2010.

Frost, B. W.: Calanus marshallae, a new species of calanoid copepod closely allied to the sibling species $C$. finmarchicus and $C$. glacialis, Mar. Biol., 26, 77-99, 1974.

Gordeev, V. V.: Fluvial sediment flux to the Arctic Ocean, Geomorphology, 80, 94-104, doi:10.1016/j.geomorph.2005.09.008, 2006.

Gorsky, G., Ohman, M. D., Picheral, M., Gasparini, S., Stemmann, L., Romagnan, J.-B., Cawood, A., Pesant, S., Garcia-Comas, C., and Prejger, F.: Digital zooplankton image analysis using the ZooScan integrated system, J. Plankton Res., 32, 285-303, doi:10.1093/plankt/fbp124, 2010.

Guidi, L., Jackson, G. A., Stemmann, L., Miquel, J. C., Picheral, M., and Gorsky, G.: Relationship between particle size distribution and flux in the mesopelagic zone, Deep-Sea Res. Pt. I, 55, 1364-1374, doi:10.1016/j.dsr.2008.05.014, 2008.

Guidi, L., Stemmann, L., Jackson, G. A., Ibanez, F., Claustre, H., Legendre, L., Picheral, M., and Gorskya, G.: Effects of phytoplankton community on production, size and export of large aggregates: A world-ocean analysis, Limnol. Oceanogr., 54, 19511963, 2009.

Ingram, R. G., Williams, W. J., van Hardenberg, B., Dawe, J. T., and Carmack, E.: Seasonal Circulation over the Canadian Beaufort Shelf, in: On Thin Ice: A synthesis of the Canadian Arctic Shelf Exchange Study (CASES), edited by: Fortier, L., Barber, D. G., and Michaud, J., Aboriginal Issues Press, Winnipeg, 1338, 2008.

Iversen, M. H., Nowald, N., Ploug, H., Jackson, G. A., and Fischer, G.: High resolution profiles of vertical particulate organic matter export off Cape Blanc, Mauritania: Degradation processes and ballasting effects, Deep-Sea Res. Pt. I, 57, 771-784, doi:10.1016/j.dsr.2010.03.007, 2010.

Jackson, G. A. and Checkley Jr., D. M.: Particle size distributions in the upper $100 \mathrm{~m}$ water column and their implications for animal feeding in the plankton, Deep-Sea Res. Pt. I, 58, 283-297, doi:10.1016/j.dsr.2010.12.008, 2011.
Karakas, G., Nowald, N., Schefer-Neth, C., Iversen, M., Barkmann, W., Fischer, G., Marchesiello, P., and Schlitzer, R.: Impact of particle aggregation on vertical fluxes of organic matter, Prog. Oceanogr., 83, 331-341, doi:10.1016/j.pocean.2009.07.047, 2009.

Kellogg, C., Carpenter, S., Renfro, A., Sallon, A., Michel, C., Cochran, J., and Deming, J.: Evidence for microbial attenuation of particle flux in the Amundsen Gulf and Beaufort Sea: elevated hydrolytic enzyme activity on sinking aggregates, Polar Biol., 34, 2007-2023, doi:10.1007/s00300-011-1015-0, 2011.

Kosobokova, K. and Hirche, H.-J.: Biomass of zooplankton in the eastern Arctic Ocean: A base line study, Prog. Oceanogr., 82, 265-280, doi:10.1016/j.pocean.2009.07.006, 2009.

Kosobokova, K. N. and Hopcroft, R. R.: Diversity and vertical distribution of mesozooplankton in the Arctic's Canada Basin, Deep-Sea Res. Pt. II, 57, 96-110, doi:10.1016/j.dsr2.2009.08.009, 2010.

Kosobokova, K. N., Hirche, H.-J., and Scherzinger, T.: Feeding ecology of Spinocalanus antarcticus, a mesopelagic copepod with a looped gut, Mar. Biol., 141, 503-511, doi:10.1007/s00227-002-0848-z, 2002.

Kriest, I. and Evans, G. T.: A vertically resolved model for phytoplankton aggregation, Proc. Indian Acad. Sci., 109, 453-469, 2000.

Legendre, L. and Michaud, J.: Flux of biogenic carbon in oceans: size-dependent regulation by pelagic food webs, Mar. Ecol. Prog. Ser, 164, 1-11, doi:10.3354/meps164001, 1998.

Li, W. K. W., McLaughlin, F. A., Lovejoy, C., and Carmack, E. C.: Smallest algae thrive as the Arctic Ocean freshens, Science, 326, 539, doi:10.1126/science.1179798, 2009.

Lansard, B., Mucci, A., Miller, L. A., Macdonald, R. W., and Gratton, Y.: Seasonal variability of water mass distribution in the southeastern Beaufort Sea determined by total alkalinity and $\delta^{18} \mathrm{O}$, J. Geophys. Res., 117, C03003, doi:10.1029/2011JC007299, 2012.

Longhurst, A. R.: Relationship between diversity and the vertical structure of the upper ocean, Deep-Sea Res. Pt. I, 32, 1535-1570, doi:10.1016/0198-0149(85)90102-5, 1985.

Macdonald, R. and Yu, Y.: The Mackenzie Estuary of the Arctic Ocean, in: The Handbook of Environmental Chemistry, edited by: Wangersky, P. J., Springer, Berlin, 91-120, 2006.

Martin, J., Tremblay, J. E., Gagnon, J., Tremblay, G., Lapoussière, A., Jose, C., Poulin, M., Gosselin, M., Gratton, Y., and Michel, C.: Prevalence, structure and properties of subsurface chlorophyll maxima in Canadian Arctic waters, Mar. Ecol. Prog. Ser., 42, 69-84, doi:10.3354/meps08666, 2010.

Mauchline, J.: The Biology of Calanoid Copepods, Advances in Marine Biology, edited by: Blaxter, J. and Southward, A., Academic Press, London, 710 pp., 1998.

McDonnell, A. M. P. and Buesseler, K. O.: Variability in the average sinking velocity of marine particles, Limnol. Oceanogr., 55, 2085-2096, 2010.

Moloney, C. L., Jarre, A., Kimura, S., Mackas, D. L., Maury, O., Murphy, E. J., Peterson, W. T., Runge, J. A., and Tadokoro, K.: Dynamics of marine ecosystems: ecological processes, in: Marine Ecosystems and Global Change, edited by: Barange, M., 9, Oxford University Press, Oxford, 179-219, 2010.

O'Brien, M. C., Macdonald, R. W., Melling, H., and Iseki, K.: Particle fluxes and geochemistry on the Canadian Beaufort Shelf: 
Implications for sediment transport and deposition, Cont. Shelf Res., 26, 41-81, doi:10.1016/j.csr.2005.09.007, 2006.

Olli, K., Wassmann, P., Reigstad, M., Ratkova, T. N., Arashkevich, E., Pasternak, A., Matrai, P. A., Knulst, J., Tranvik, L., Klais, R., and Jacobsen, A.: The fate of production in the central Arctic Ocean - top-down regulation by zooplankton expatriates?, Prog. Oceanogr., 72, 84-113, doi:10.1016/j.pocean.2006.08.002, 2007.

Picheral, M., Guidi, L., Stemmann, L., Karl, D. M., Iddaoud, G., and Gorsky, G.: The Underwater Vision Profiler 5: An advanced instrument for high spatial resolution studies of particle size spectra and zooplankton, Limnol. Oceanogr. Methods, 8, 462473, 2010.

Platt, T. and Denman, K. L.: The structure of pelagic marine ecosystems, Rapp. P.-v. Reun. Cons. int. Explor. Mer,, 173, 60-65, 1978.

Razouls, C., de Bovée, F., Kouwenberg, J., and Desreumaux, N.: Diversity and Geographic Distribution of Marine Planktonic Copepods, http://copepodes.obs-banyuls.fr/en, 2005-2011.

Remsen, A., Hopkins, T. L., and Samson, S.: What you see is not what you catch: a comparison of concurrently collected net, Optical Plankton Counter, and Shadowed Image Particle Profiling Evaluation Recorder data from the northeast Gulf of Mexico, Deep-Sea Res. Pt. I, 51, 129-151, doi:10.1016/j.dsr.2003.09.008, 2004.

Richardson, T. L. and Jackson, G. A.: Small phytoplankton and carbon export from the surface ocean, Science, 315, 838-840, doi:10.1126/science.1133471, 2007.

Sakshaug, E.: Primary and Secondary Production in the Arctic Seas, in: The Organic Carbon Cycle in the Arctic Ocean, edited by: Stein, R. and MacDonald, R. W., Springer-Verlag, NewYork, 57-81, 2004.

Sampei, M., Forest, A., Sasaki, H., Hattori, H., Makabe, R., Fukuchi, M., and Fortier, L.: Attenuation of the vertical flux of copepod fecal pellets under Arctic sea ice: evidence for an active detrital food web in winter, Polar Biol., 32, 225-232, doi:10.1007/s00300-008-0523-z, 2009.

Seuthe, L., Darnis, G., Riser, C. W., Wassmann, P., and Fortier, L.: Winter-spring feeding and metabolism of Arctic copepods: insights from faecal pellet production and respiration measurements in the southeastern Beaufort Sea, Polar Biol., 30, 427-436, doi:10.1007/s00300-006-0199-1, 2007.
SLGO: Satellite Imagery (Remote Sensing) Public Archives, St. Lawrence Global Observatory, http://slgo.ca/en/remotesensing/ data.html, 2011.

Stemmann, L. and Boss, E.: Particle and plankton size and packaging: from determining optical properties to driving the biological pump, Ann. Rev. Mar. Sci., 4, 263-290, doi:10.1146/annurevmarine-120710-100853, 2012.

Stemmann, L., Jackson, G. A., and Ianson, D.: A vertical model of particle size distributions and fluxes in the midwater column that includes biological and physical processes Part I: model formulation, Deep-Sea Res. Pt. I, 51, 865-884, doi:10.1016/j.dsr.2004.03.001, 2004.

Stemmann, L., Youngbluth, M., Robert, K., Hosia, A., Picheral, M., Paterson, H., Ibanez, F., Guidi, L., Lombard, F., and Gorsky, G.: Global zoogeography of fragile macrozooplankton in the upper 100-1000 $\mathrm{m}$ inferred from the underwater video profiler, ICES J. Mar. Sci., 65, 433-442, doi:10.1093/icesjms/fsn010, 2008.

Suzuki, N. and Sato, K.: Studies on suspended particles. Marine snow in the sea. I. Source of marine snow, Bulletin of the Faculty of Fisheries of Hokkaido University, 4, 132-137, 1953.

Tremblay, J.-É., Simpson, K., Martin, J., Miller, L. A., Gratton, Y., and Price, N. M.: Vertical stability and the annual dynamics of nutrients and chlorophyll fluorescence in the coastal, southeast Beaufort Sea J. Geophys. Res., 113, C07S90, doi:10.1029/2007JC004547, 2008.

Tremblay, J.-É., Bélanger, S., Barber, D. G., Asplin, M., Martin, J., Fortier, L., Darnis, G., Gratton, Y., Link, H., Archambault, P., Williams, W. G., Philippe, B., and Gosselin, M.: Climate forcing multiplies biological productivity in the Arctic Ocean, Geophys. Res. Lett., 38, L18604, doi:10.1029/2011GL048825, 2011.

Wassmann, P., Olli, K., Wexels Riser, C., and Svensen, C.: Ecosystem function, biodiversity and vertical flux regulation in the twilight zone, in: Marine science frontiers for Europe, edited by: Wefer, G., Lamy, F., and Mantoura, F., Springer Verlag, Berlin, 279-287, 2003.

Wexels Riser, C., Wassmann, P., Reigstad, M., and Seuthe, L.: Vertical flux regulation by zooplankton in the northern Barents Sea during Arctic spring, Deep-Sea Res. Pt. II, 55, 2320-2329, doi:10.1016/j.dsr2.2008.05.006, 2008.

Zhou, M.: What determines the slope of a plankton biomass spectrum?, J. Plankton Res., 28, 437-448, doi:10.1093/plankt/fbi119, 2006.

Zhou, M., Carlotti, F., and Zhu, Y.: A size-spectrum zooplankton closure model for ecosystem modelling, J. Plankton Res., 32, 1147-1165, doi:10.1093/plankt/fbq054, 2010. 